\title{
Epidemiology and aetiology of hepatocellular carcinoma in Sub-Saharan Africa
}

\section{Daniel Mak, Anna Kramvis}

Hepatitis Virus Diversity Research Unit, Department of Internal Medicine, School of Clinical Medicine, University of the Witwatersrand, Johannesburg 2193, South Africa.

Correspondence to: Prof. Anna Kramvis, Hepatitis Virus Diversity Research Unit, Department of Internal Medicine, School of Clinical Medicine, University of the Witwatersrand, 7 York Road, Parktown, Johannesburg 2193, South Africa. E-mail:

Anna.Kramvis@wits.ac.za

How to cite this article: Mak D, Kramvis A. Epidemiology and aetiology of hepatocellular carcinoma in Sub-Saharan Africa. Hepatoma Res 2021;7:39. https://dx.doi.org/10.20517/2394-5079.2021.15

Received: 10 Feb 2021 First Decision: 24 Mar 2021 Revised: 27 Mar 2021 Accepted: 13 Apr 2021 Published: 17 May 2021

Academic Editors: Guang-Wen Cao, Antonio Bertoletti Copy Editor: Yue-Yue Zhang Production Editor: Yue-Yue Zhang

\begin{abstract}
With the highest annual fatality ratio (mortality-to-incidence ratio), reported for a human cancer, hepatocellular carcinoma (HCC) ranks as the third leading cause of cancer-related deaths worldwide and its distribution is not uniform. In Sub-Saharan Africa (SSA), HCC is the second leading cause of cancer-related deaths for men and the fourth for women in 2020, with average age-standardised mortality rates of 8.2 and 4.2 per 100,000 persons/year, respectively. In this region, HCC presents in younger age groups and has a median survival rate of 3-4 months. The major risk factors for HCC include viral [hepatitis B virus (HBV), hepatitis C virus (HCV) and hepatitis D virus (HDV)] and environmental [dietary aflatoxin and iron overload] factors, with more than $50 \%$ being attributable to HBV, which is endemic in SSA. HCC control efforts in SSA are faced with a number of unique challenges, including resource restrictions, a paucity of good data, few cancer registries, inaccessibility of treatment for HBV and HCV, co-infection with human immunodeficiency virus (HIV), exposure to co-carcinogen aflatoxin B1, unique (sub)genotypes of HBV and changing natural history and aetiology of $\mathrm{HCC}$ as a result of antiretroviral therapy rollout for HIV and changing lifestyles. These unique features of HCC in SSA, together with the challenges faced in its prevention and appropriate public health intervention, diagnosis and treatment, all suggest that HCC in SSA is deserving of an in depth understanding by further focused research. Considerable motivation of policymakers, work and resources are required to reduce the burden of this cancer on the subcontinent.
\end{abstract}

Keywords: Liver cancer, hepatitis, Africa, carcinogens, risk factors 


\section{GLOBAL DISTRIBUTION OF PRIMARY LIVER CANCER}

Primary liver cancer (PLC) as a primary cancer includes hepatocellular carcinoma (HCC), intrahepatic cholangiocarcinoma and other rare types, with the exclusion of secondary liver cancer. HCC, which originates from hepatocytes, is the most common histological subtype, constituting $75 \%-90 \%$ of the total PLC cases diagnosed globally. As the most frequently diagnosed subtype, HCC is often used interchangeably with PLC. With an annual fatality ratio (mortality-to-incidence ratio) of 0.92 as determined when using GLOBOCAN 2020 data (the highest reported for a human cancer worldwide), PLC ranks as the third leading cause of cancer-related deaths worldwide (8.2\% of total cancer-related deaths in 2020$)^{[1,2]}$. Globally, the distribution of PLC is non-uniform and of all the new cases recorded in 2020, the vast majority occurred in regions such as Asia and Africa ${ }^{[1,2]}$.

The continent of Africa encompasses a wide geographic area of 30.4 million square kilometres and is the world's second largest continent, making up $6 \%$ of the Earth's total surface, and consisting of many lowmiddle income countries (LMICs). With 1.34 billion people ${ }^{[3]}$, Africa is also the second most inhabited continent and accounts for $16 \%$ of the global population. The majority ( $83.6 \% ; 1.1$ billion) of the African population lives to the south of the Sahara Desert that covers the northern third of the continent. Although both North African and SSA countries share the same continent, they differ in regards to climate and ethnic and cultural backgrounds of their populations. In particular, as a consequence of historical migrations, North African countries are closely tied to the Middle East and parts of Europe ${ }^{[4]}$. Therefore, almost every distinctive feature of cancer in Africa prevails predominantly in SSA, and none more so than PLC ${ }^{[5]}$.

\section{INCIDENCE AND SURVIVAL RATES OF LIVER CANCER IN SUB-SAHARAN AFRICA}

In 2020, SSA had the fourth highest number of diagnosed PLC cases worldwide after South-Eastern Asia, South Central Asia and Northen America, with more than 38,000 new cases of PLC ${ }^{[2]}$. Of all PLCs in SSA, $77 \%$ are HCCs (varying from $67 \%$ to $88 \%$ by region). Globally, the second leading subtype is intrahepatic cholangiocarcinoma (CCA) that arises from the biliary epithelium and constitutes the remaining 15\%-20\% of diagnosed PLC cases $^{[-8]}$. Other rare forms that account for fewer than $1 \%$ of cases include angiosarcoma (inner lining of blood vessels), hepatoblastoma (hepatocyte precursors) and epithelioid haemangioendothelioma (endothelial cells) ${ }^{[5,6,9]}$. Very few studies have differentiated between these PLCs in $\mathrm{SSA}^{[8]}$. In a systematic review that included three studies performed in SSA, one in Nigeria and two in South Africa, it was concluded that there was no gender disparity and that the major risk factors for CCA, including primary sclerosing cholangitis, Clonorchi sinensis and Opisthorchis viverrini infection, are rare in this setting ${ }^{[10]}$. In SSA, PLC is the second leading cause of cancer-related death for men and the fourth for women in 2020. The high fatality rate in SSA black Africans suggests that the recorded annual death from the malignancy is virtually the same as the number of cases diagnosed in the population at that time, thus highlighting the inadequacy in the preventive, screening and treatment programs that are currently available on this subcontinent.

Figure 1, compiled using data from the International Agency for Research In Cancer (IARC) registry in $2008^{[11]}, 2012^{[12]}, 2018^{[13]}$ and $2020^{[2]}$ illustrates that age-standardised incidence rates (ASIRs) are not uniform in SSA. Western and Central Africa are characterised by decreases in ASIRs in both sexes between 2018 and 2020, whereas an increase occurred in both sexes in Western Africa and in Eastern African women only in the most recent year. The average ASIR of HCC in Sub-Saharan African men and women is 18.9 and 8.0 per 100,000 persons/year, respectively ${ }^{[14]}$. 


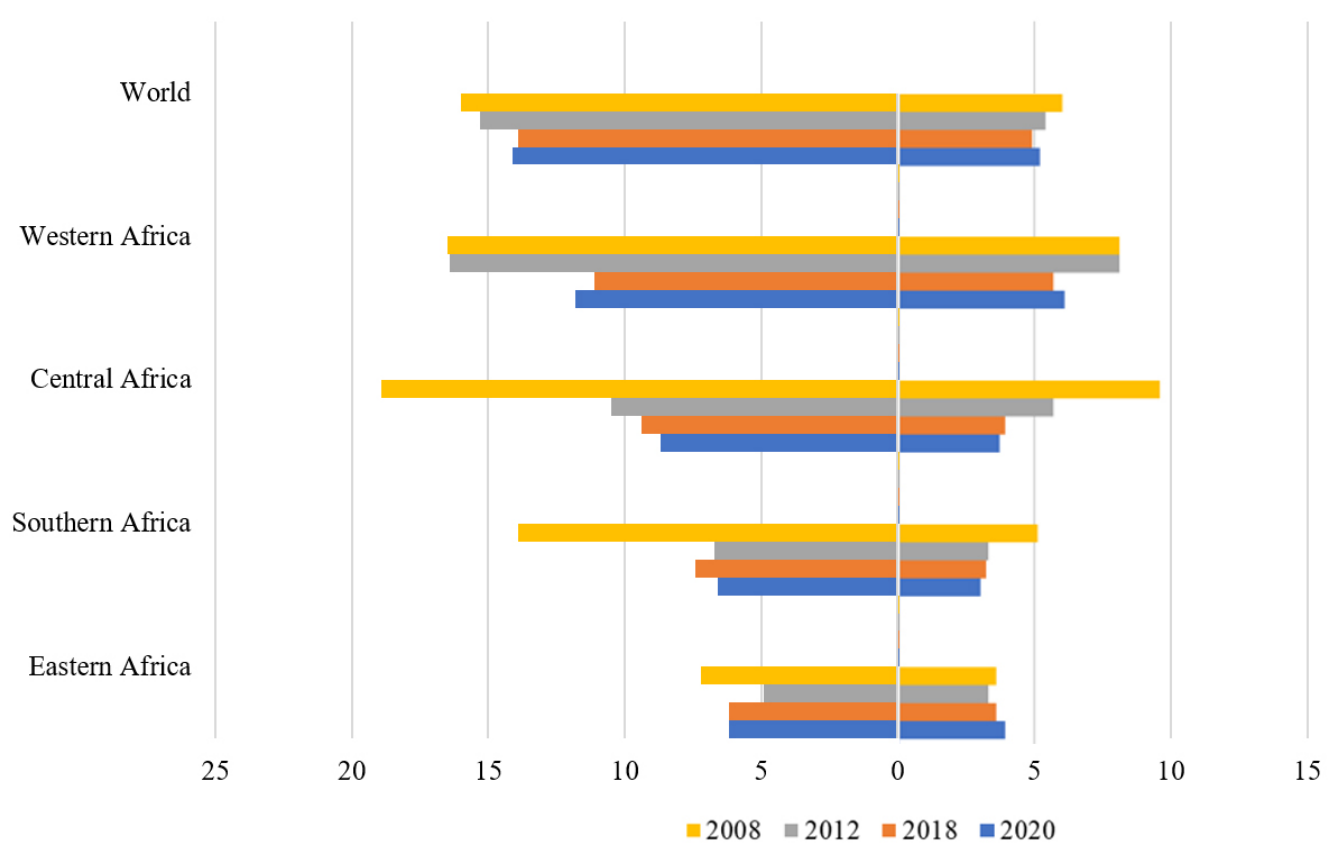

Figure 1. Liver cancer age-standardised incidence rate (ASIR) per 100,000 persons-year in 2008, 2012, 2018 and 2020, compiled using data from ${ }^{[2,11-13]}$ respectively. ASIR for men are shown on the left and women on the right of the histogram.

According to GLOBOCAN $2020^{[2]}$, variations in the ASIR also occur between different countries in SSA. Of the 11 West African countries, The Gambia and Guinea have high rates (ASIR > 20) and the remaining nine (Benin, Burkina Faso, Cote d'Ivoire, Guinea Bissau, Ghana, Nigeria, Togo, Niger and Mali) have intermediate incidences $(5<$ ASIR $<20)$. In Central Africa, the incidence is intermediate in the Republic of Congo and low in Cameroon and Gabon. Of the 10 East African countries, four (Kenya, Zimbabwe, Uganda and Rwanda) and seven (Malawi, Ethiopia, Tanzania, Mauritius, Zambia, Reunion, Mozambique) have intermediate and low incidences (ASIR < 5), respectively. Of the four Southern African countries, two have intermediate incidences (Botswana and Swaziland) and the remaining (Namibia and the Republic of South Africa) have a low incidence of PLC.

In other reports, the frequency of PLC was expressed in another way: the tumour accounted for $1.9 \%$ of all malignant diseases in Nigeria (2009-2013) ${ }^{[15]}, 2.2 \%$ in Malawi (2008-2010), 4\% in Uganda (1991-2010) $)^{[16]}, 5 \%$ in Eastern Cape Province, South Africa (1998-2012) $)^{[17]}$ and 7.6\% in Zimbabwe (2006) $)^{[18]}$. In The Gambia, $60 \%$ of all malignant diseases in men and $20 \%$ of those in women are $\mathrm{PLC}^{[19]}$. According to the National Cancer Registry of The Gambia, covering the years 1990-2009, The Gambia, one of the poorest countries in the world ${ }^{[20]}$, has the highest recorded incidence of PLC among Sub-Saharan African countries (31.6 and 16.9 per 100,000 persons/year in men and women, respectively ${ }^{[19]}$, which is higher than that recorded by GLOBOCAN $2020^{[2]}$. Notably, this reported incidence rate is 3.4 and 5 times higher than that in white men and women in the United States, respectively ${ }^{[21]}$.

Even within SSA countries, the frequency of PLC is not equally distributed. This phenomenon is most obvious in South Africa, where the tumour occurs appreciably more often in rural inhabitants and at a younger age than in their urban counterparts ${ }^{[14]}$. In a more recent study, HCC was significantly associated with a rural birthplace $(P<0.05)$, being male and living in an urban area for 14 years or less ${ }^{[22]}$. It is likely that these variations at the subcontinental and local level reflect the disparities in the geographical distribution of certain environmental, viral and socioeconomic factors that all, to some extent, play a 
contributory role in the development of PLC.

Despite these findings, published incidences of PLC in the Sub-Saharan African subcontinent are believed to underestimate its true burden as a consequence of the many instances where the malignancy is either inconclusively diagnosed or is not recorded in a cancer registry ${ }^{[14]}$. It has been suggested that the limited number of reliable cancer registries in SSA and the challenges associated with diagnosing PLC as a result of scarce resources are the major reasons for the under-diagnosis and under-reporting of PLC. SSA continues to have low coverage of high-quality population-based cancer registration with $<5 \%$ population coverage, with low or no mortality registration quality ${ }^{[23]}$. Most missed PLC cases were predicted to occur in resource limited settings, with 11 of the top 15 countries in terms of underestimation being in SSA ${ }^{[24]}$.

Moreover, from the available data, it is evident that the survival rate of people with PLC in SSA is generally poor, wherein these rates are much lower than that reported in East Asia and even more so when compared to developed countries ${ }^{[25-27]}$. The median survival rate of PLC patients in North Africa is significantly higher than that of SSA: 10.9 (95\%CI: 9.6-12.0) months in Egypt compared to 2.5 (95\%CI: 2.0-3.1) months in other African countries $(P<0.0001)^{[28]}$. In South Africa, the mean survival period of rural blacks is only 6 weeks from diagnosis and 11.2 weeks from the onset of symptoms ${ }^{[29]}$ and in The Gambia the median survival of HCC patients was estimated at 91 days (range: 4-789 days) ${ }^{[30]}$. The 5-year survival rate of patients with PLC in Uganda and The Gambia is 3.2\% ${ }^{[31]}$ and $3 \%{ }^{[32]}$, respectively, much lower than $9 \%$ in Denmark ${ }^{[33]}$ and $14.8 \%$ (whites: $14.3 \%$ and blacks: $11.3 \%$ ) in the $\mathrm{USA}^{[34]}$. In a recent study that looked at PLC mortality trends in South Africa between 1999 and 2015, it was evident that mortality rates are influenced by age, sex and race $^{[35]}$. The mortality rates increased with age and are higher among black Africans compared to whites in all age groups-with a peak black African-to-white mortality rate ratio of 6 in men and 3 in women at ages 30-39 years. The average mortality-to-incidence ratio for black African men and women was 4 and 3.3, respectively, compared to 2.2 and 1.8 in their white counterparts ${ }^{[35]}$. Similarly, in the USA, blacks are more likely to have larger tumour size, more advanced tumour stage/with metastatic disease and lower levels of alpha-fetoprotein and are less likely to present with cirrhosis ${ }^{[2,36]}$. These disparities in results between the USA and SSA are more likely a consequence of differing prevalence rates of major risk factors including [hepatitis B virus (HBV) and/or hepatitis C virus (HCV)], obesity and diabetes ${ }^{[37]}$, as well as lack of resources, which may limit access to high-quality care ${ }^{[38]}$. Considering that, in SSA, most cases of PLC are only detected during the advanced stages of the disease, resectability is only $1 \%-2 \%$, and remission or prolongation of survival are seldom achieved ${ }^{[29]}$.

Another distinctive feature of PLC in SSA that can be inferred from previous case studies is that the disease presents at a much younger age when compared to those found in regions outside of Africa. The median age of diagnosis of HCC (interquartile range, IQR; range) is 45 years (35-57; 8-95), being three years younger in men than in women. Moreover, the median age of patients with HBV-associated HCC is 42 years compared to 55 years in those with HCV alone and 47 years in HBV/HCV co-infected individuals ${ }^{[28,39]}$. In the USA, those of African descent are more frequently diagnosed with PLC at a younger age than Caucasians ${ }^{[40]}$. However, as cautioned by Shimakawa and Lemoine ${ }^{[41]}$, these studies should be interpreted with care because there are very few longitudinal studies from Africa ${ }^{[42]}$ and the median age of the African population is significantly lower than that of non-African countries. Therefore, the carrying out of more HCC surveillance studies in order to determine age-specific incidence of PLC would be highly beneficial.

The unique features of HCC in SSA, together with the challenges faced in its prevention and appropriate public health intervention, diagnosis and treatment ${ }^{[43-45]}$, all suggest that PLC in SSA is deserving of an in 
depth understanding, with the carrying out of more focused research studies.

\section{AETIOLOGY AND RISK FACTORS FOR HCC IN SSA}

Similar to most other cancers, HCC is a multistage disease that results from a culmination of pathologically induced damages that evolve over time. However, unlike most other cancers, HCC is unique in that it develops in the context of well-known and readily identifiable risk factors including viral [HBV, HCV and hepatitis D virus (HDV)], host (hereditary haemochromatosis) and environmental (dietary aflatoxin, alcohol exposure, iron overload, obesity and diabetes mellitus) factors ${ }^{[14,46,47]}$. Other risk factors that are still under investigation include cigarette smoking, oral contraceptives and human immunodeficiency virus (HIV) infection. HCC almost invariably occurs in the setting of histologically abnormal liver such as chronic hepatopathy and/or cirrhosis ${ }^{[48,49]}$ or in association with genetic disorders such as haemochromatosis, Wilson's disease, alpha 1-antiprotease (antitrypsin) deficiency and cystic fibrosis ${ }^{[50]}$.

It is well established that neoplastic lesions usually originate on a bed of chronic necroinflammation that sequentially progresses from fibrosis to cirrhosis and finally culminates in HCC. However, cirrhosis is not a condition sine qua non in HCC development. Interestingly, a proportion (10\%-57\%) of HCC cases may occur in the non-fibrotic or minimal fibrotic liver ${ }^{[51-53]}$, which may suggest a possible shift in the underlying aetiology of HCC, particularly in developed regions of the world ${ }^{[54]}$. In Western countries, this progression towards the malignancy arises in $46 \%$ of patients, with a history of anabolic steroid use and metabolic syndrome (obesity and diabetes mellitus) that is associated with non-alcoholic fatty liver disease $(\mathrm{NAFLD})^{[55-57]}$. In less developed countries, non-cirrhotic HCC occurs in chronic viral hepatitis patients more frequently than in the more developed Western countries: $53 \%$ of the cases in South Africa ${ }^{[58]}$ compared to only $9.5 \%$ in the USA ${ }^{[59]}$. However, the reduced frequency of cirrhosis may be a consequence of lack of detection rather than its absence because resource constraints in SSA obviously limit access to examination by biopsy. In SSA, the cirrhosis is macronodular, typically asymptomatic, and it is caused predominantly by chronic HBV infection, whereas, in low-incidence regions such as the USA, the cirrhosis, although usually macronodular, it may be micronodular, is commonly symptomatic and caused by HCV infection, prolonged alcohol abuse, metabolic syndrome and hereditary hemochromatosis ${ }^{[60]}$.

While various reasons may account for these differences, geographic locations as an indicator of varying aetiological risk factors may be one possible explanation. Genetic differences may be another reason. Exome sequencing has led to the identification of gene expression signatures in $\mathrm{HCC}^{[1]]}$ and an algorithm for molecular classification of HCC has been developed ${ }^{[62,63]}$. One particular signature is found to be highly associated with HCC patients of African origin, younger than 63.5 years, with $\mathrm{HBV}$ infection, high $\mathrm{C}>\mathrm{A}$ and p53 mutations. This molecular signature is not associated with cirrhosis, alcohol consumption or smoking ${ }^{[6]]}$. Further subtype classification has been attempted using multiplex molecular profiling of HCC $^{[64]}$. Broadly, transcriptome analysis delineated a proliferative and a non-proliferative HCC type, which differ in histological, molecular, epigenetic and immunological features, oncogenic pathway activation, phenotype and prognosis ${ }^{[6,65,66]}$. Chronic HCV infection and alcohol consumption are aetiological factors associated with the non-proliferative HCC, which is characterised by low levels of AFP, retention of welldifferentiated cancer cells and relatively good prognosis ${ }^{[62,65,67]}$. Proliferative HCC, characterised by high serum AFP levels, leads to more aggressive tumours and poor prognosis and is associated with HBV infection $^{[2,65,67]}$. This unifying molecular classification aims to lead to stratified therapy strategies ${ }^{[68]}$. However, this classification has been based on studies carried out on HCC patients from Asia, Europe and North America, in which African and indigenous populations have been under-represented. In the largest, integrative genomic analysis carried out by the Cancer Genome Atlas Research Network, only 7\% (14 of 196) of HCC samples were classified as black or African ${ }^{[64]}$. Thus, more research is required to confirm that 
this classification holds in HCC from under-represented populations. Indeed, HCC from indigenous American ancestry could not be classified using this unified classification system ${ }^{[6]}$. It is interesting to note that Peruvians display early-onset HCC with relatively low HBV DNA viral loads ${ }^{[70]}$, comparable to what is observed in Southern African HCC patients infected with Subgenotype A $1^{[1,72]}$.

\section{Hepatitis viruses}

Mono-infection from HBV and HCV are well-established independent risk factors for HCC and the relative importance of each virus varies globally ${ }^{[73]}$. It is reported that, of the 770,000 cases of HCC that occurred worldwide in 2012, more than half (56\%; 95\%CI: 52\%-60\%) were attributable to HBV and 20\% (95\%CI: $18 \%$ $22 \%$ ) to $\mathrm{HCV}^{[7,75]}$. $\mathrm{HCV}$ is the leading cause of $\mathrm{HCC}$ in Egypt (84\%), whereas HBV is the leading cause in other African countries $(55 \%)^{[28]}$, where hepatitis B surface antigen (HBsAg)-positivity predominates compared to anti-HCV in HCC patients ${ }^{[76]}$. In SSA, 50\% of all liver cancers are attributable to HBV and $17 \%$ to $\mathrm{HCV}^{[77]}$. Overall, only $3 \%$ of HCC patients in Africa are co-infected with HBV and HCV ${ }^{[28,77]}$. It is interesting to note that the risk factors for PLC also differ between southern and western SSA. In southern SSA, $40 \%$ of HCC are attributed to alcohol consumption, $29 \%$ to HBV, $20 \%$ to HCV and $11 \%$ to other factors; the respective figures for western SSA are $29 \%, 45 \%, 11 \%$ and $15 \%{ }^{[78]}$. Limited data from SSA intimate that HDV infection may play a role in hepatocarcinogenesis in this region.

\section{Hepatitis B virus}

$\mathrm{HBV}$, a small-enveloped DNA pararetrovirus with an RNA intermediate, is the prototype of the family Hepadnaviridae, genus Orthohepadnavirus. HBV is the second most important human carcinogen following tobacco smoking ${ }^{[79]}$ and was responsible for 887,000 deaths in $2015^{[80]}$. Accordingly, HBV is one of the most important aetiological risk factors for hepatocarcinogenesis ${ }^{[81]}$. The worldwide prevalence rates for HBV infection vary from $0.1 \%$ to more than $20 \%{ }^{[82]}$. In particular, HBV causes approximately two out of three cases of PLC in less developed countries, with most cases aggregating in East Asia and SSA ${ }^{[74]}$.

\section{Epidemiology}

An estimated $70 \%-98 \%$ of adult black Africans show serological evidence of previous exposure to $\mathrm{HBV}^{[84]}$ and an estimated 65-70 million are chronically infected with $\mathrm{HBV}^{[85]}$. This is probably an underestimate as a result of a paucity of good quality data from $\mathrm{SSA}^{[45]}$. Six of the top 10 sources of uncertainty in the global estimate in adults were SSA nations, with the corresponding number in children, aged 5 years, being 8/10. The two SSA countries, Nigeria and the Democratic Republic of the Congo (DRC), together with India and Indonesia account for about $57 \%$ of HBV infections globally, with SSA having the highest prevalence in children aged 5 years ${ }^{[86]}$.

Different geographical regions have been categorised into four distinct groups based on the viral serological prevalence of the HBsAg: high ( $\geq 8 \%)$, higher-intermediate (5\%-7.99\%), lower-intermediate (2\%-4.99\%) and low $(<2 \%)$ [Figure 2] ${ }^{[83,87]}$. Except for Algeria, Eritrea and the Seychelles, most countries in Africa are of higher-intermediate endemicity [South Africa (6.7\%), Zambia (6.1\%) and Kenya (5.2\%)] or highly endemic for HBV [Swaziland (19\%), Zimbabwe (14.4\%), Cameroon (12.2\%) and Mozambique (8.3\%)]. This high prevalence of HBsAg corresponds to the high incidence of HCC in SSA. It is known that in this region HBV infection mainly occurs at a young age, with most acquiring HBV before the age of 30 years $(81.5 \%$ and $71.4 \%$ in South Africa and Togo, respectively) ${ }^{[1,88]}$, and thus are at a high risk of developing HCC (relative risk ranging from 9-23.3 $)^{[89]}$.

\section{Transmission}

The transmission of HBV occurs predominantly by percutaneous or mucosal exposure to infected blood and other body fluids of an infected person. Mother-to-child (perinatal/vertical) remains the most common 


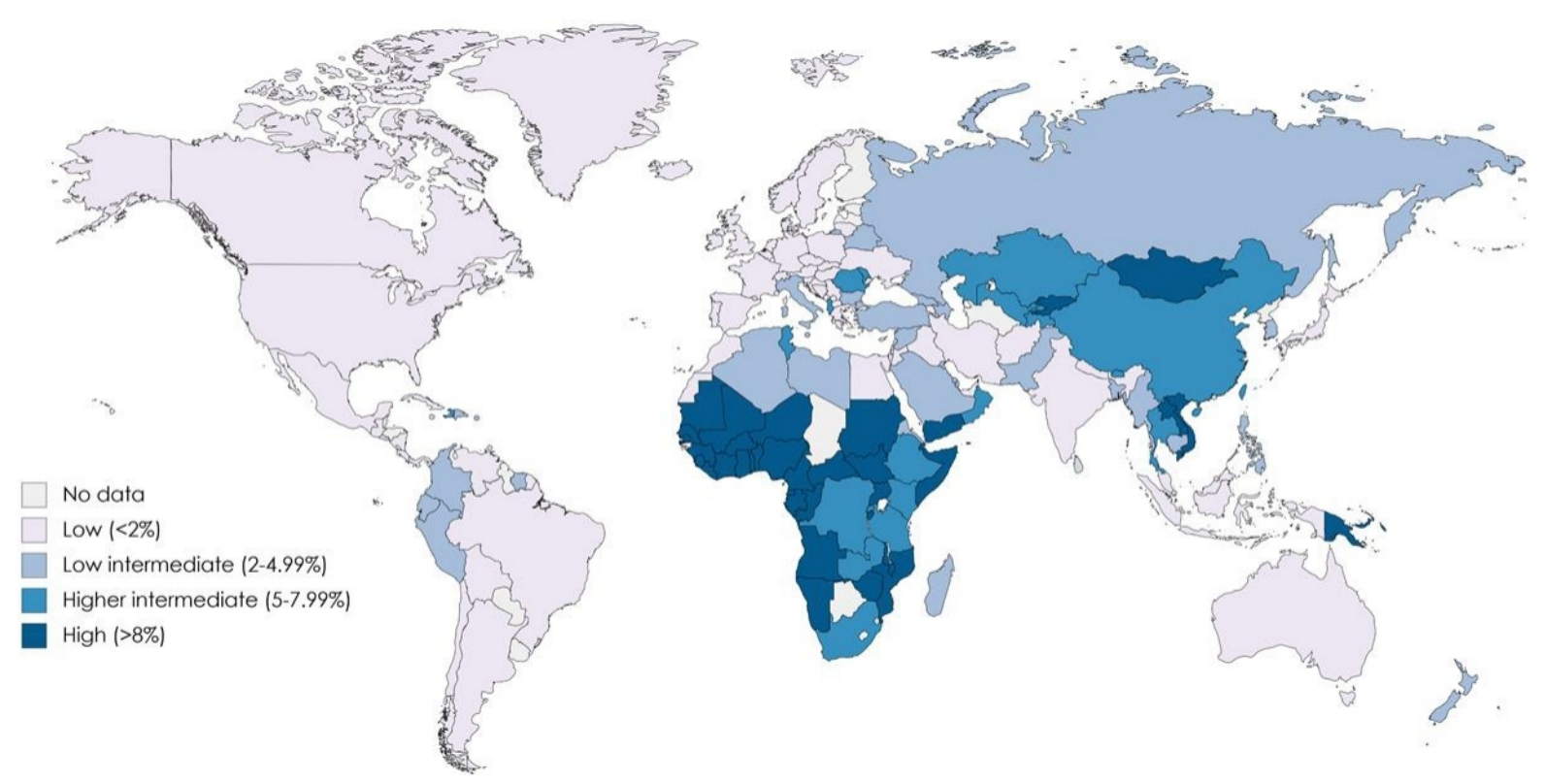

Figure 2. Global prevalence of Hepatitis B Virus (HBV) infection, compiled using data from ${ }^{[83]}$. The map was created from https://mapchart.net.

route of viral transmission in areas of high prevalence such as Asia, whereas unprotected sexual contact or intravenous drug use are the main routes of infection in areas of low prevalence, such as Canada ${ }^{[00]}$. Thus, the latter cases only acquire the infection later in life, with the majority (95\%) experiencing spontaneous resolution of acute infection ${ }^{[91]}$. In contrast, in SSA, most infections are acquired horizontally within the first five years of life ${ }^{[92,93]}$, presumably via contact with household members, unsafe injection practices and medical procedures ${ }^{[94]}$, tribal tattooing, scarification and circumcision practices ${ }^{[44]}$. In a population-based case-control study in The Gambia, compared to controls, HCC cases had earlier birth order, a proxy for young maternal age and maternal $\mathrm{HBV}$ viraemia at birth, suggesting that perinatal transmission may increase the risk of $\mathrm{HCC}^{[95]}$. Unlike East Asia, perinatal transmission of HBV in SSA is less important, partly because of the lower frequency of hepatitis B e antigen (HBeAg)-positivity, which is a major determinant of perinatal transmission ${ }^{[92,96,97]}$. Studies from the pre- or early HBV immunisation period have reported very high infection rates in infants with HBsAg prevalence exceeding 10\% in Sub-Saharan African countries including Nigeria ${ }^{[98]}$, Senegal ${ }^{[99]}$ and South Africa ${ }^{[100,101]}$. In these populations, fewer than $10 \%$ resolve the acute infection, with the remainder progressing onto various sequelae related to chronic hepatitis B, including cirrhosis, liver decompensation or $\mathrm{HCC}^{[91]}$.

\section{Place of residence}

Comparison of HBV exposure and carrier rate between rural- and urban-born Africans is important to the epidemiology of the virus, considering that a vast majority of the population reside in rural areas in SSA. More specifically, rural-born and urban-born black Africans show variation in the burden of HBV-related HCC. In a study of 380 black Africans with HCC in South Africa, Kew et al. ${ }^{[102,103]}$ observed that those born and residing in a rural environment (45\%) had a higher rate of HBsAg alone (anti-HCV negative) than rural-urban (37\%) and urban-born (18\%) black Africans. Moreover, rural-born and -residing HCC cases are diagnosed at a younger age than those who migrate to urban cities and their urban-born and -residing counterparts (34.75 years vs. 50.9 years vs. 46.7 years, respectively) ${ }^{[103]}$. For the period 2000-2012, a higher prevalence of previous exposure to HBV was found in rural-born than in urban-born South African adult HCC cases $(65 \%$ vs. $35 \%, P<0.001)$ who were also born prior to the introduction of routine HBV 
vaccination in $1995^{[22]}$. However, in agreement with an earlier study carried out in the $1980 \mathrm{~s}^{[104]}$, there was a lack of statistical significance in HBsAg-positivity between rural ${ }^{[105]}$ and urban-born cases $(P=0.3)^{[22]}$. Thus, HCC participants born in urban environments are just as likely to have been infected with HBV during early childhood when compared to those born in rural areas and subsequently moved to an urban area ${ }^{[106]}$. Thus, the differences in incidence and age of onset of HCC in rural and urban southern African Blacks cannot be attributable to differences in HBV status alone ${ }^{[104]}$. Exposure to co-carcinogens such as dietary exposure to aflatoxin ${ }^{[107]}$ and iron overload ${ }^{[108]}$ may be more frequent in rural rather than urban environments and said exposure is minimised when these individuals move from rural to urban environment ${ }^{[104]}$.

\section{Viral loads}

From studies in Asia, higher viral loads of HBV have been shown to be a risk factor for the development of HCC $^{[105,109,110]}$. Such studies are limited in Sub-Saharan African populations. Among $124 \mathrm{HBs}$ Ag-positive HCC cases and 125 asymptomatic carriers (ASCs) of HBV identified in a cohort of black Southern Africans, the reported geometric mean viral loads were 553,618 copies/mL $(\sim 118,000 \mathrm{IU} / \mathrm{mL})$ and 16,084 copies $/ \mathrm{mL}$ $(\sim 3400 \mathrm{IU} / \mathrm{mL})$, respectively ${ }^{[111]}$. In a Sudanese study, HCC patients were found to have higher median viral load compared to patients with chronic or acute hepatitis, cirrhosis and ASCs ${ }^{[112]}$. In a Kenyan study, consisting of a small number of HCC patients, viral loads did not differ significantly when compared to those in ASCs, cirrhotics and chronic hepatitis patients ${ }^{[113]}$. Low to moderate HBV DNA levels were associated with the risk of HCC in a Senegalese cohort of men with $\mathrm{HCC}^{[110]}$. In a Gambian case-control study, comparing HCC cases with HBsAg-positive ASCs, HBV DNA levels were found to be strongly associated with HCC independent of HBeAg status. The risk increased notably above 10,000 copies/mL $(\sim 2000 \mathrm{IU} / \mathrm{mL})^{[114]}$. Similarly, in a South African case-control study comparing HCC cases to unrelated cancer controls, the risk of HCC increased with increasing HBV DNA levels above the threshold of 2000 $\mathrm{IU} / \mathrm{mL}$, in a dose-response manner ${ }^{[22]}$. However, whereas the latter study showed a negligible risk at levels lower than $2000 \mathrm{IU} / \mathrm{mL}$, the former study showed some risk. This discrepancy in risk at low HBV-DNA levels may be attributed to marked differences in population characteristics, controls used and HBV genotypes, all of which may influence the amount of viral load. Genotype E prevails in The Gambia, whereas Subgenotype A1 is the dominant HBV strain in South Africa. Genotype E-infected individuals are characterised by a higher frequency of HBeAg-positivity compared to individuals infected with Subgenotype $\mathrm{Al}^{[115]}$. Moreover, environmental risk factors in West Africa such as aflatoxin $\mathrm{B} 1\left(\mathrm{AFB}_{1}\right)^{[43]}$, which is classified as a human carcinogen by IARC, may play an important role, especially at low viral loads. In fact, in vitro experiments have shown that exposure to $\mathrm{AFB}_{1}$ can lead to reduced viral replication ${ }^{[116]}$. In the 1980s, aflatoxin contamination in South African commercial foodstuffs was shown to be low (0.66 $\mu$ $\mathrm{g} / \mathrm{kg}$ ) in comparison to Mozambique (ranging $0.7-6.43 \mu \mathrm{g} / \mathrm{kg}$ ) ${ }^{[117]}$. This was also confirmed in another study in 2004 which reported low rates of mycotoxin contamination in staple foods such as maize in South Africa $^{[118]}$. In any case, suppression of HBV, even if only for a finite period, may significantly reduce risk for developing $\mathrm{HCC}^{[119]}$. Long-term follow-up studies are needed to further determine the role of low HBV DNA levels as a risk factor for HCC in SSA.

\section{Occult HBV infection}

Functional cure is defined as the loss of HBsAg and is used as an endpoint for current anti-HBV therapies. However, the risk of HCC is not eliminated with the loss of HBsAg.

Occult HBV infection (OBI) is defined as the presence of replication-competent HBV DNA [i.e., episomal HBV covalently closed circular DNA (cccDNA)] in the liver and/or HBV DNA in the blood of people who test negative for HBsAg by currently available assays ${ }^{[120,121]}$. OBI retains several of the oncogenic mechanisms of overt $\mathrm{HBV}$, including production of pro-oncogenic proteins and the propensity of the viral DNA to 
integrate into the host's genome ${ }^{[122,123]}$. A $12 \%$ prevalence of OBI was previously reported in South African HCC cases $^{[22]}$, which was significantly lower than that reported in an earlier South African study $(48.4 \%)^{[124]}$. When adjusted for sex, age group, country and province of birth, number of years lived in urban area, place of birth, alcohol consumption, HIV status and anti-HCV, the associated odds ratio (OR) for HCC in black South Africans was found to be 2.60 (95\%CI: 0.90-7.53) for seronegative OBI, increasing to 5.10 (95\%CI: 2.06-12.62) for anti-HBc-positive $\mathrm{OBI}^{[22]}$. This risk is consistent with a previous meta-analysis of retrospective studies $(\mathrm{OR}=6.08 ; 95 \% \mathrm{CI}: 3.45-10.72)^{[125]}$.

\section{Genotypes, subgenotypes and mutants}

In areas with a high prevalence of HBV, such as Southeast Asia and SSA, there is a corresponding high incidence of HCC, with an attributable fraction $(\mathrm{AF})^{[126]}$ (estimated by combining HBV prevalence with the risk for HCC) of $69 \%$ and $50 \%$ in these regions, respectively ${ }^{[74]}$. The different genotypes prevailing in these two geographical regions may be responsible for this observed difference in $\mathrm{AF}^{[127]}$. $\mathrm{HBV}$ is classified into at least nine genotypes, A-I, with a 10th putative genotype. Genotypes A, D and E circulate in SSA, with Subgenotype A1 being the prevalent subgenotype of Genotype $\mathrm{A}^{[85]}$, which has been shown to have a higher hepatocarcinogenic potential than other (sub)genotypes ${ }^{[7]}$. Various mutations occurring in this and other (sub)genotypes have been shown to occur more frequently in HBV isolated from HCC patients ${ }^{[128,129]}$. For example, basic core promoter (BCP) mutations (1753V and 1762 T/1764A), preS2 deletion, preS2 initiation codon and ps2 $222 \mathrm{~L}$ mutations were more frequent in strains isolated from HCC patients than in those from non-HCC controls ${ }^{[112,113,130,131]}$. The combination of BCP and preS2 mutations may suggest the emergence of naturally occurring immune escape variants with a persistent HBV infection that leads to HCC development. A higher prevalence of cancer-related HBV mutations 1762T/1764A and PreS deletions were isolated from HBV/HIV co-infected compared to HBV-mono-infected Chinese adults ${ }^{[132]}$. As suggested previously ${ }^{[133]}$, these mutations may be potential biomarkers that can be used for screening high-risk individuals for developing HCC. Such a screening strategy is cost-effective, which is important in resourcelimited regions such as SSA.

\section{Hepatitis D virus}

HDV, the only member of the genus Deltavirus, is a satellite virus of HBV, sharing the HBV entry receptor and utilising the HBV envelope proteins for infection, morphogenesis and propagation ${ }^{[134,135]}$. Thus, HDV can only be transmitted in the presence of a concomitant HBV infection, by coinfection or superinfection. With a RNA genome of $\sim 1700$ base pairs, it is the smallest agent infecting humans ${ }^{[136]}$. In the latest estimates, 12.0 (95\%CI: 8.7-18.7) million people globally were projected to be anti-HDV positive, representing $0.16 \%$ (95\%CI: $0.11 \%-0.25 \%$ ) of the general population, $4.5 \%$ (95\%CI: 3.6\%-5.7\%) among HBsAg-positive people and $16.4 \%$ (95\%CI: $14.6 \%-18.6 \%)$ among those attending hepatology clinics $^{[137]}$. This estimate is considerably lower than those obtained in another study, which found $0.98 \%$ (95\%CI: $0.61 \%-1.42 \%$ ) in the general population and $14.57 \%$ (95\%CI: $12.93 \%-16.27 \%$ ) in HBsAg-positive individuals ${ }^{[138]}$. However, there were concerns about the populations selected, the markers and the HBsAg prevalence estimates used in the latter study that may have introduced biases ${ }^{[139]}$.

HDV is classified into eight genotypes. A high diversity of genotypes prevails in SSA including Genotypes 1 and 5-8, with Genotypes 5-8 previously reported only in SSA, Genotype 5 in West Africa and Genotypes 6-8 in Central Africa. However, strains belonging to these genotypes are being reported in Europe ${ }^{[138]}$ as a result of migrations from SSA ${ }^{[140]}$.

Relatively few HDV studies, with small sample sizes, mainly using antibody assays and a minority using nucleic acid detection, have been performed in SSA. In fact, there have been performance issues and 
difficulties with the detection of African HDV Genotypes 5-8 $8^{[141]}$. SSA is characterised with localised clusters of HDV endemicity, with pooled seroprevalence of HDV in the general population of $7.33 \%$ (95\%CI: 3.55\%$12.20 \%$ ) in West Africa and 25.64\% (95\%CI: 12.09\%-42.00\%) in Central Africa, with the corresponding values in liver disease patients being 9.57\% (95\%CI: 2.31\%-20.43\%) and 37.77\% (95\%CI: 12.13\%-67.54\%), respectively. In south-eastern Africa, with a paucity of data and none for liver disease patients, the percentage in the general population was considerably lower at $0.05 \%(0.00 \%-1.78 \%)^{[142]}$.

Co-infection of HBsAg-positive individuals with HDV can accelerate progression to cirrhosis and $\mathrm{HCC}^{[136]}$. Globally, the population AF of HDV among HBsAg-positive individuals was found to be $20 \%$ for cirrhotics and $18 \%$ for HCC patients ${ }^{[137]}$. However, in SSA, there is a significant knowledge gap on the role of HDV in serious liver disease and HCC, with most studies being performed more than 10 years ago. When 300 HBsAg-positive Mauritanian liver disease patients were tested for anti-HDV and HDV RNA, 30\% were seropositive, with $62.2 \%$ of these being RNA positive. Co-infected patients were $>8$ years older than HBVmono-infected patients, with anti-HDV antibody, in addition to male sex and higher HBV viral loads being associated with advanced liver fibrosis ${ }^{[143]}$. In Senegal, $24 \%$ of HBsAg-positive liver disease patients were anti-HDV positive compared to only $7 \%$ in controls with no liver disease ${ }^{[144]}$. A study of 53 liver disease patients in Ghana found $11.3 \%$ were anti-HDV-positive, including $5.3 \%$ of 19 HCC patients ${ }^{[145]}$. In a case control study comparing HCC with patients without liver disease, the prevalence of HBsAg, anti-HCV and anti-HDV were significantly higher in HCC patients $(65.90 \%, 20.26 \%$ and $26 \%$, respectively) than in control patients $\left(9.23 \%, 4.62 \%\right.$ and $1 \%$, respectively) $\left(P<2.5 \times 10^{-5}\right)$. There was a $16-, 10-$ and 29 -fold odds ratio increased HCC risk in HBV, HCV and HDV infections, respectively. The authors concluded that the highest hepatocarcinogenic viral factor in Cameroon is $\mathrm{HDV}^{[146]}$. However, more studies are required to confirm this in SSA, especially considering the high estimated prevalence of anti-HDV among general HBsAg-positive populations of $8.39 \%$ (95\%CI: 4.73\%-12.85\%) ${ }^{[142]}$. These studies should increase the number of patients tested, with standardised and sensitive methods, including nucleic acid testing specific for Genotypes 5-8. Furthermore, because SSA is the epicentre of the HIV epidemic and antivirals for HIV are active against HBV and hence HDV, treated and treatment-naïve patients should be differentiated when testing for HDV. To facilitate large general population-based HDV studies in SSA, the use of dried blood spots, for both antibody and RNA assays, has been suggested ${ }^{[147]}$.

\section{Hepatitis $C$ virus}

$\mathrm{HCV}$ is a hepatotropic RNA virus of the family Flaviviridae and the genus Hepacivirus. High prevalence rates of more than 3.5\% are reported in Central Africa; moderate prevalence of $1.5 \%-3.5 \%$ are reported in East and North Africa; and low prevalence of less than $1.5 \%$ are reported in Southern Africa ${ }^{[148]}$. HCV strains have been classified into 8 genotypes and 105 subgenotypes $^{[149-151]}$. HCV genotypes differ at $30 \%-35 \%$ of nucleotide sites, whereas subgenotypes of the same genotype differ by $<15 \%{ }^{[152]}$. Subgenotypes $1 \mathrm{a}, 1 \mathrm{~b}, 2 \mathrm{a}$ and 3a have a global distribution ${ }^{[152-154]}$. Genotypes 1, 2, 4 and 5 have endemic origins in Africa, with Genotypes 1 and 2 occurring throughout Africa, Genotype 4 in Egypt and parts of Central Africa and Genotype 5 in southern Africa and less commonly in some parts of Central Africa ${ }^{[155]}$. Two full-length coding sequences of Genotype 7 have been characterised. Both sequences were identified in the $\mathrm{DRC}^{[156,157]}$. The high diversity of HCV in SSA suggests that the virus was endemic in this region before its global dispersal 100-200 years ago. Very few African studies have looked at the effect of HCV genotype on the risk of HCC. In Cameroon, patients infected with HCV Genotype 4, in particular Subgenotype $4 \mathrm{f}$ or with core gene variants, are at a higher risk of developing $\mathrm{HCC}^{[158]}$. The initial spread of Subgenotype 5a, which prevails in South Africa, was estimated in the 1950s, later than the initial spread in Japan, Europe and the USA, and thus it is proposed that the progression of HCV-associated HCC will occur later as well ${ }^{[159]}$. 
With no studies in some African countries or limited studies with small sample sizes in other countries, accurate HCV prevalence data are difficult to obtain ${ }^{[160]}$. The overall HCV seroprevalence in SSA is $3.0 \%$ with an estimated viraemic (HCV RNA) prevalence of $1.0 \%$ (0.7\%-1.6\%) or 11.0 (7.0-16.0) million HCVinfected individuals ${ }^{[161]}$. The prevalence of HCV varies in the different regions of SSA: West Africa has relatively high prevalence ranging from $1 \%$ in Senegal to $6.1 \%$ in Burkina Faso with good evidentiary support. The highest prevalence is in Central Africa ranging from $2.1 \%$ in the DRC to $~ 5 \%$ in Cameroon and Gabon, with extensive studies having been undertaken in this region. Eastern Africa has a prevalence range from $1.3 \%$ in Mozambique to $2.8 \%$ in Kenya where there is limited to extensive evidentiary support. Southern Africa, with its limited studies, has the lowest prevalence ranging from $1.1 \%$ in South Africa to $1.6 \%$ in Namibia and Zimbabwe ${ }^{[160]}$.

In a meta-analysis of 21 case-control studies, it was shown that patients who tested positive for anti-HCV had a 17-fold increased risk of developing HCC compared to HCV-negative controls (95\%CI: 14-22) (162]. $^{\text {. }}$ $\mathrm{HCV}$ is associated with HCC development mainly through indirect pathways such as chronic inflammation, cell apoptosis and proliferation. Up to $16 \%$ of HCV-infected persons develop cirrhosis 20 years after the infection ${ }^{[163]}$. The annual incidence of HCC in HCV-induced cirrhosis is on average $2 \%-3 \%^{[164]}$. The natural history of $\mathrm{HCV}$ is highly variable with host and environmental factors playing a role in progression to cirrhosis in patients chronically infected with this virus. Factors such as older age ${ }^{[165]}$, older age at HCV acquisition ${ }^{[165]}$, male $\operatorname{sex}^{[165]}$, heavy alcohol intake ${ }^{[166]}$, aflatoxin exposure ${ }^{[167]}$, smoking ${ }^{[166]}$, diabetes ${ }^{[168]}$, obesity ${ }^{[169]}$ and co-infection with $\mathrm{HIV}^{[170]}$ or $\mathrm{HBV}^{[171,172]}$ have all been implicated in enhancing the development of cirrhosis in patients with chronic HCV infection and ultimately leading to HCC.

Early on it was recognised that HCV has a smaller, albeit significant role in the development of HCC in southern African Blacks ${ }^{[102,173]}$. Relative to individuals serologically negative for HBV and/or HCV, those positive for HBsAg alone have a significant increased risk of 23.3 for HCC, whereas those positive for antiHCV alone have a statistically significant risk of 6.6. A synergistic effect on risk was evident when markers for both viruses were present (relative risk, 82.5) ${ }^{[174]}$. Higher proportions of women and urban dwellers, and with a higher average age, present with HCV-associated HCC, compared to those with HBV-associated HCC $^{[102,173]}, 37.5$ years $v$ s. 57.3 years, respectively ${ }^{[174]}$. In a study carried out in the USA, it was concluded that there are differences in the risk of HCC development, which are dependent on the race of the HCV-infected individuals: African Americans are at a considerably lower risk of developing cirrhosis and HCC than are Hispanics and non-Hispanic whites ${ }^{[175]}$.

\section{$\mathrm{AFB}_{1}$}

$\mathrm{AFB}_{1}$ is a powerful hepatocarcinogen that contributes to high morbidity and mortality. Produced by the fungus Aspergillus species (A. flavus and A. parasiticus), $\mathrm{AFB}_{1}$ is commonly detected in several food products including peanuts, grain, cereals, legumes and $\operatorname{corn}^{[176]}$. In particular, $\mathrm{AFB}_{1}$ is widespread in regions where food products are poorly stored in conditions that are unsanitary and high in temperature and humidity-mostly in tropical regions of SSA and Southeast Asia, including China. It is estimated that 4.5 billion people are at risk of chronic exposure to $\mathrm{AFB}_{1}$-contaminated food ${ }^{[177]}$. Of the 550,000-600,000 new HCC cases worldwide each year, about 25,200-155,000 (4.6\%-28.2\%) may be attributable to aflatoxin exposure $^{[167]}$.

When ingested, the process of metabolising $\mathrm{AFB}_{1}$ produces an active substrate known as $\mathrm{AFB}_{1}$-exo-8,9epoxide by CYP450 enzyme (CYP1A2 isoform) that plays an important role in the development of HCC. The substrate binds the guanine bases on the third base of codon 249 of the $p 53$ gene to form aflatoxin-N7guanine $\left(\mathrm{AFB}_{1}-\mathrm{N} 7-\mathrm{Gua}\right)^{[178,179]}$, which can be detected in $36 \%-50 \%$ of HCC tumour samples collected from 
individuals in $\mathrm{AFB}_{1}$-endemic areas, most of whom have $\mathrm{HBV}$ infections ${ }^{[180-182]}$. Assays have been developed to detect and measure $\mathrm{AFB}_{1}$ metabolites in urine ${ }^{[183]}$, serum ${ }^{[184]}$ and tissues ${ }^{[185]}$.

It has been reported that $\mathrm{HBV}$ infection is prevalent in regions with high $\mathrm{AFB}_{1}$ contamination, including SSA, Southeast Asia and China ${ }^{[14,183]}$. Although $\mathrm{AFB}_{1}$ might have direct hepatocarcinogenic effects, its role in the pathogenesis of HCC is primarily as a co-carcinogen to that of chronic HBV infection ${ }^{[107]}$. For example, a previous study using transgenic mice demonstrated that HBV infection, specifically the HBV X protein, modulates the DNA GC $\rightarrow$ TC transversion at position 249 of the $p 53$ gene mutation by as much as twofold when exposed to $\mathrm{AFB}_{1}{ }^{[186]}$. In a prospective study in China, individuals exposed to $\mathrm{AFB}_{1}$ had a four-fold increased risk of developing HCC, and this risk increased to 60-fold in individuals who were also carriers of $\mathrm{HBV}^{[183]}$. In a recent Gambian study, $\mathrm{AFB}_{1}$ exposure was significantly associated with $\mathrm{HCC}$ risk (crude $\mathrm{OR}=5.0 ; 95 \% \mathrm{CI}: 1.5-17.2$ ) with a multiplicative effect of $\mathrm{AFB}_{1}$ exposure and $\mathrm{HBV}$ preS2 deletions on HCC risk ${ }^{[131]}$. More longitudinal and in depth studies are required in SSA to determine the exact roles of the different co-carcinogens in HCC development, together with public health awareness and education campaigns to minimise $\mathrm{AFB}_{1}$ contamination in staple foods.

\section{Hereditary haemochromatosis and iron overload}

Hereditary haemochromatosis $(\mathrm{HH})$ is an autosomal recessive disorder common among people of Northern European origin that leads to the accumulation of iron in various organs of the body, including the liver ${ }^{[187]}$. This pathophysiologic predisposition of iron overload may lead to the development of cirrhosis and ultimately HCC. The mutated human haemochromatosis gene, HFE, located on the short arm of chromosome $6^{[188,189]}$, leads to increased iron absorption and progressive iron storage that results in liver damage and fibrosis, which may eventually lead to $\mathrm{HCC}^{[190]}$. Risks estimates of HH for HCC of 200 in earlier studies ${ }^{[191,192]}$ and 20 in more recent ones ${ }^{[193]}$ have been reported. HH is uncommon in Africans ${ }^{[187]}$ but has been reported in Cameroonians ${ }^{[194]}$, South Africans ${ }^{[195]}$ and African Americans ${ }^{[196]}$.

Studies in African populations have found that patients with iron overload are not associated with the $\mathrm{HH}$ mutation as reported in Northern Europeans ${ }^{[197]}$, but it is instead a consequence of drinking traditional beer containing dissolved iron that occurs from using iron drums and cans in which the beer is brewed ${ }^{[198]}$. With the replacement of traditional brewing drums with plastic containers, this source of iron overload may be decreasing, but there are no recent studies to substantiate this. Mandishona et al. ${ }^{[195]}$ reported a relative risk of HCC of 10.6 (95\%CI: 1.5-76.8) when compared to individuals with normal iron status and a population attributable risk of 29 in rural South African Blacks, after adjusting for the confounding effects of $\mathrm{HBV} / \mathrm{HCV}$ infection and exposure to $\mathrm{AFB}_{1}$. Although the possible causal role of cirrhosis could not be determined in this study because the histological material was obtained by percutaneous biopsy, previous studies have suspected that the deposited iron in hepatocytes and macrophages may play a role in liver organ damage, thus leading to the development of cirrhosis ${ }^{[199]}$. Even though the hepatocarcinogenicity of hepatic iron overload has been confirmed in animal models ${ }^{[200,201]}$, many confounding factors, including the consumption of alcohol, makes it difficult to determine whether iron has a direct or indirect role in hepatocarcinogenesis ${ }^{[202]}$.

The almost universal association between cirrhosis and the subsequent onset of HCC strongly suggests that chronic necroinflammatory hepatic disease as a result of excess hepatic iron indirectly causes malignant transformation of hepatocytes, as it does with most other causes of HCC. However, studies investigating dietary iron overload in Southern African black populations demonstrated increased risk of HCC development even after adjusting for the confounding effect of cirrhosis ${ }^{[203,204]}$. The mechanisms responsible for a direct hepatocarcinogenic effect of iron have yet to be fully defined, although oxidative stress has been 
proposed as a mechanism ${ }^{[200]}$. A multiplicative synergy has been demonstrated between $\mathrm{AFB}_{1}$ and iron overload $^{[205]}$.

In addition to the four major aetiological factors of HCC in SSA discussed, several risk factors are emerging $^{[161]}$ and becoming progressively more important as Western lifestyles are being adopted. Data on other potential factors associated with lifestyle behaviours (alcohol, smoking and non-alcoholic liver disease) influencing HCC rate are limited in SSA, with our recent study showing minimal effects in South African HCC patients ${ }^{[22]}$.

\section{Alcohol and smoking}

As the primary site of alcohol metabolism, the liver is a primary target for alcohol-related injury. Substantial epidemiological data consistently show that excessive consumption of alcohol is associated with increased risk of HCC development, particularly in European and American populations, where chronic HBV infection is less prevalent. For example, studies from the USA, Italy and Taiwan reported $32 \%, 45 \%$ and $21 \%$ of HCC cases are attributable to alcohol consumption, respectively ${ }^{[206,207]}$. In a cross-sectional study that investigated the burden of alcohol consumption in South Africa, researchers observed relative risk of developing PLC in both men and women ranging from 1.5 to $3.6^{[208]}$. Furthermore, another South African study demonstrated a four-fold increased risk of HCC after correcting for HBV infection ${ }^{[209]}$. It has been suggested that alcohol may be associated with HCC only as a consequence of the development of cirrhosis $^{[210]}$. In addition, it has been suggested that daily ingestion of more than $80 \mathrm{~g}$ of alcohol for more than 10 years is generally required before there is significant risk of developing cirrhosis ${ }^{[211}$, and it has been shown to have an equivalent increase risk of developing $\mathrm{HCC}^{[210]}$. It should be noted that alcohol-induced HCC can develop in the absence of cirrhosis, and even if one abstains from alcohol consumption after cirrhosis has developed ${ }^{[212]}$. In South Africa, excessive alcohol consumption has been implicated as a major risk factor for HCC in older white (mean age of 60 years) ${ }^{[213]}$ and urban black African men (older than 40 years $)^{[209]}$. Alcohol has also been suggested to be a risk factor for HCC in patients with no markers for hepatitis viruses in a large African study ${ }^{[39]}$. Following the global trend, total alcohol per capita consumption among drinkers ( $\geq 15$ years) in litres of pure alcohol have increased in SSA over the period of 2000-2016 $6^{[214]}$. As with other risk factors, alcohol consumption may act as a co-carcinogen together with HBV infection in the development of $\mathrm{HCC}^{[206]}$.

In South Africa, even though anti-smoking legislation and increased prices of cigarettes have contributed to a decreased consumption by $33 \%$ from 1993 to $2003^{[215]}$, several studies conducted prior to this legislation found little or no support for causal relation between cigarette smoking and HCC development in $\mathrm{SSA}^{[209,216]}$, and this has been supported more recently in South Africa ${ }^{[22]}$ and The Gambia ${ }^{[95]}$.

However, it is important to note that earlier epidemiological studies that investigated the association between smoking and HCC have been inconsistent, and these inconsistencies vary between different population groups and in the presence of potential confounders ${ }^{[217]}$. With regards to earlier cohort studies conducted in the USA ${ }^{[218]}$, Japan ${ }^{[219]}$ and Greece ${ }^{[220]}$, the reports all show evidence of increased risks of PLC among smokers with some also reporting an increase in a dose-response relationship ${ }^{[220,221]}$. This is inconsistent with other studies that found no risk ${ }^{[222]}$ or reported inconclusive evidence ${ }^{[223]}$. In a metaanalysis of 38 cohort studies and 58 case-control studies from Europe (Norway and Sweden), North America (the USA) and East Asia (China, Japan, Taiwan, Korea and Philippines), the authors reported that, relative to never smokers, the adjusted relative risk was 1.51 (95\%CI: 1.37-1.67) for current smokers and 1.12 (95\%CI: 0.78-1.60) for former smokers ${ }^{[224]}$. An updated meta-analysis of 81 epidemiological studies supported this association with significant pooled ORs for HCC development of 1.55 (95\%CI: 1.46-1.65) and 
1.39 (95\%CI: 1.26-1.52) for current and former smokers, respectively, compared to non-smokers. The OR was dose dependent ${ }^{[225]}$. This association was further substantiated by the identification of two of the eight molecular signatures associated with HCC, also being associated with tobacco exposure ${ }^{[61]}$. Furthermore, Nnitrosodimethylamine, a component in cigarette smoke, has been shown to be hepatocarcinogenic in animals ${ }^{[226-228]}$ and various mechanisms have been proposed for the hepatocarcinogenic effect of smoking ${ }^{[229]}$. The IARC has included PLC on the list of carcinomas associated with smoking ${ }^{[230]}$. Thus, while awaiting further studies on smoking and HCC in SSA, smoking should be considered as a risk factor for HCC.

\section{Non-alcoholic liver disease and diabetes}

In a study that selected a total sample size of more than 8.5 million cases from 22 countries, it was reported that the global prevalence rate of NAFLD was estimated to be $25.2 \%$ (95\%CI: $22.1 \%-28.6 \%)^{[231]}$. The authors also showed that the highest prevalence occurred in the Middle East, followed by South America, Asia, the USA and Europe, and the lowest in Africa. These findings were reported despite the apparent paucity of studies investigating NAFLD, as shown in Figure $3^{[231]}$. While NAFLD and its inflammatory component non-alcoholic steatohepatitis (NASH) are responsible for the third leading cause of death in developed regions of the world ${ }^{[232]}$, HCC remains the primary cause of death in this group ${ }^{[233]}$.

In NAFLD/NASH related HCC, several risk factors have been identified including metabolic syndrome and insulin resistance, which lead to changes in the inflammatory cytokines and/or adipokines ${ }^{[234]}$, persistent inflammation and altered gut microflora and bile composition ${ }^{[235-237]}$. In a meta-analysis of cohort studies from mainly developed countries (Europe, the USA, Japan and Korea), the summary relative risk of PLC was 1.89 (95\%CI: $1.51-2.36)$ for those who were obese compared with persons of normal weight ${ }^{[238]}$. It is likely that NAFLD/NASH plays a role in the increased risk of Sub-Saharan Africans developing HCC, especially considering that changing eating habits, sedentary lifestyles and the wide roll out of antiretroviral therapy (ART) against HIV might be contributing factors to the increasing adiposity and diabetes seen in SSA between 2000 and $2014^{[239]}$.

\section{Hormonal contraception}

Studies that investigated PLC risk with oral contraceptives use in high-risk Asian and African women uniformly yielded inconclusive or null results. In these regions, it is difficult to determine whether these findings can be explained because of the non-synergistic effect of viral (HBV) and hormonal factors, given that detecting the risk associated with oral contraceptive use (2-3-fold) against the very high background relative risk (20-fold) in HBV carriers may be particularly difficult ${ }^{[46]}$. Nevertheless, some biological and experimental evidence suggests a possible role of oral contraceptives in hepatocarcinogenesis. In in vitro experiments, oestrogen was reported to stimulate the cellular proliferation of HepG2 cells ${ }^{[240,241]}$ and the rate of spontaneous mutation ${ }^{[242]}$. In patients, increased risk of liver disease associated with oral contraceptive use was observed in pills containing more than $50 \mu \mathrm{g}$ of oestrogen, and regression in disease was noted after cessation of contraceptive use $\mathrm{e}^{[24-245]}$. These findings all suggest that contraceptive use may have potential hepatocarcinogenic effects, which may be dependent on various factors that include the period of exposure, dosage levels and the influence arising from confounding factors. Further long-term prospective studies in SSA could help in elucidating the role of oral contraceptives in hepatocarcinogenesis.

\section{HIV}

Of the almost 38 million HIV-positive individuals globally ${ }^{[246]}$, approximately two-thirds reside in SSA. HBV-HIV coinfection occurs in $10 \%$ of HIV-infected individuals ${ }^{[8,247]}$, and this increases to $25 \%$ when taking OBI into account ${ }^{[248,249]}$. HCV-HIV co-infection ranges from $0.7 \%$ to $16 \%$ in SSA ${ }^{[247]}$. Clearly, the HIV epidemic has had a major demographic and health impact. The clinical consequences of HBV-HIV coinfection include higher mortality and morbidity compared to individuals who are mono-infected with 


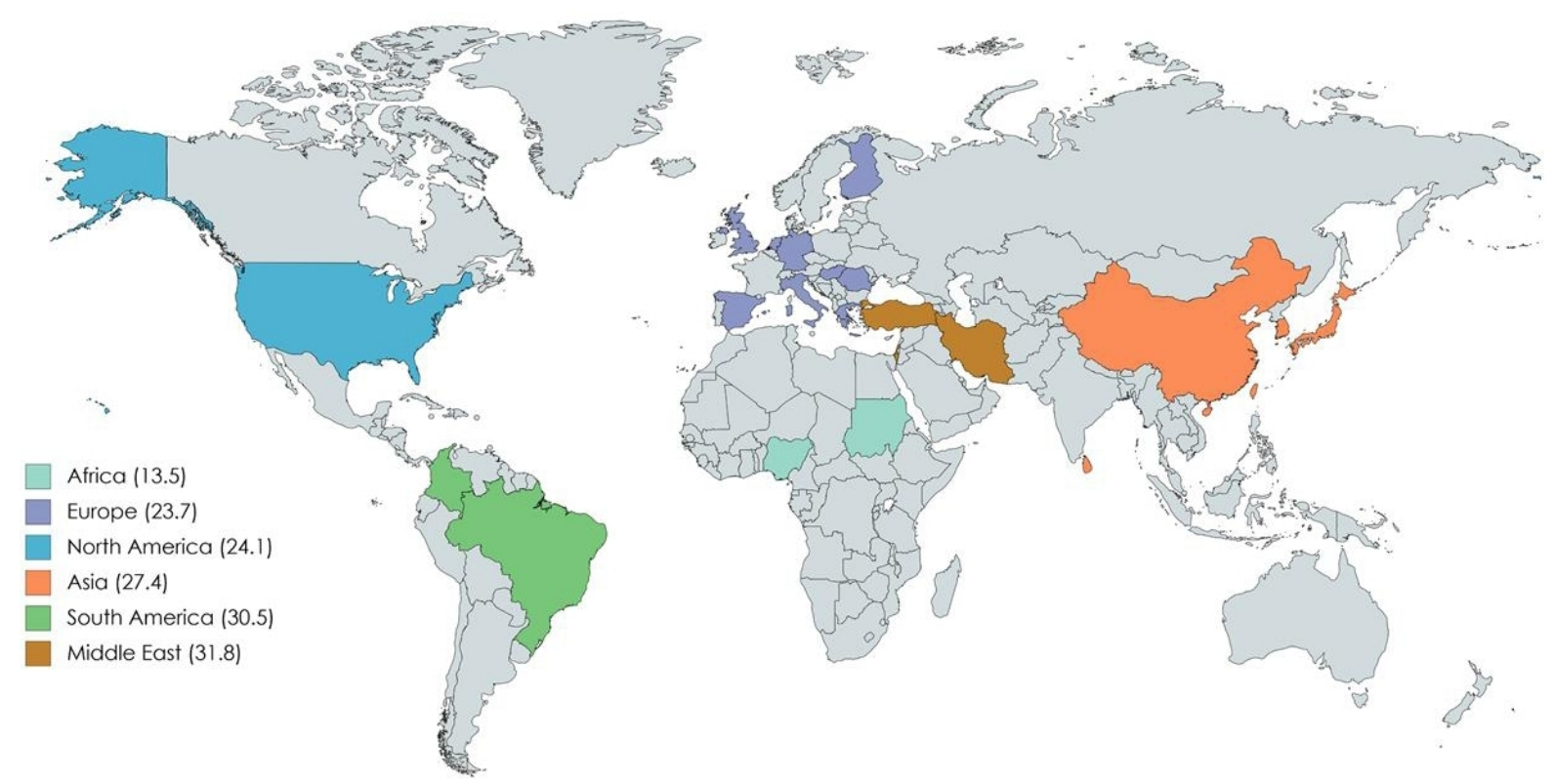

Figure 3. Non-alcoholic Liver Disease and Diabetes (NAFLD) prevalence stratified by region, data obtained from ${ }^{[231]}$ and compiled with https://mapchart.net.

either virus ${ }^{[250]}$. The progression of chronic hepatitis B to cirrhosis and HCC is more rapid in HIV-positive individuals than in those with HBV alone. HIV immunosuppression can cause the loss of anti-HBs and lead to HBV reactivation. HBV can also negatively impact HIV outcomes ${ }^{[251]}$, with ART changing the disease profile and increasing mortality attributed to HBV-associated end-stage liver disease $\mathrm{e}^{[252]}$.

Studies carried out prior to the ART era in South Africa and Uganda failed to show increases in HCC risk among HIV-infected persons, possibly due to the competing risks of AIDS-related deaths ${ }^{[253,254]}$. However, an increase in HCC cases has been noted in the ART era in developed countries ${ }^{[255]}$. Moreover, with the scale up of ART treatment in South Africa, from 4.9\% adults accessing ART in $2004^{[256]}$ to $61 \%$ in $2009^{[257]}$, an upswing in PLC mortality rates in black Africans occurred ${ }^{[35]}$. In Uganda, a study reported that, with each $10 \%$ increase in ART coverage, PLC incidence increased by $12 \%^{[258]}$. The spectrum of liver disease may be shifting from opportunistic infections to sequelae of chronic HBV/HCV infections, medication toxicities, alcoholism and fatty liver ${ }^{[259]}$, possibly as a result of increased longevity following ART. These associations need to be further investigated in case-control and cohort studies in SSA to determine the underlying aetiological risk factors in this group. Moreover, there is a need for focused PLC control efforts and further investigations in ART-treated HIV-infected cohorts who are now surviving longer.

\section{CONCLUSIONS AND FUTURE PROSPECTS}

HCC control efforts in SSA are faced with a number of challenges, which are unique to this sub-continent:

-Most countries in this region are LMICs, with resource constraints in terms of both human capacity and infrastructure.

·HBV continues to be hyperendemic, with West Africa having HBsAg-prevalence of more than $8 \%$. 
-Less than $1 \%$ of HBV-positive individuals and even fewer HCV-positive individuals are aware of being infected. In SSA, 1.1 million $(<1 \%)$ of about 60-80 million chronic carriers are diagnosed and only 33,000 $(<$ $1 \%)$ of those are receiving treatment ${ }^{[86]}$.

$\cdot \mathrm{HDV}$ is a neglected infection in this region.

-Antenatal HBV screening is hardly performed in SSA $(0 \%-20 \%)^{[260]}$.

.Only $\sim 10 \%$ of newborns receive the birth dose of $\mathrm{HBV}$ vaccine.

-Direct antiviral agents against HCV are inaccessible to most patients because of high prices.

.Contamination of staple foodstuffs with the co-carcinogen $\mathrm{AFB}_{1}$ is not controlled.

.The epicentre of the HIV pandemic is in SSA.

-There is a paucity of good quality data on HCC in this region.

-Very few genomic studies, necessary for the molecular classification of HCC, have been done in patients from SSA.

-The number of cancer registries is limited.

·Extensive ART implementation is changing the natural history of HCC.

·Emerging lifestyle changes may also be influencing the aetiology of HCC.

-The HBV genotypes/subgenotypes prevailing in SSA are diverse, with distinct geographical distribution within Africa and differing from those circulating outside the subcontinent. Considering that viral genotypes and subgenotypes have a role to play in the clinical manifestation of the infection, the results from studies investigating HBV-related HCC from other regions cannot necessarily be extrapolated directly to SSA.

Progress in surveillance, prevention and diagnosis of HBV, HDV and HCV infections can play a great role in the successful management of HCC in SSA and the reduction of its serious consequences. There is an urgent need for targeted screening of HCC, especially in high-risk groups. This will provide much needed data, which will inform public health officials and determine the various factors that are at work. Prevention is pivotal in controlling the clinical consequences of HBV infection. Although nationwide HBV vaccination programs have been successfully implemented in SSA, positively contributing to the decline in HBV seroprevalence in children, vaccination is suboptimal because only $\sim 10 \%$ of neonates have access to the birth dose. Furthermore, there remains a group of unvaccinated adults who were born prior to the introduction of the HBV vaccine, who are ageing, with increased risk for HCC. Access to treatment should be improved. Although HBV/HIV co-infected individuals receive ART treatment that can also manage HBV infection, HBV mono-infected individuals find it very difficult to access treatment in SSA. HBV infection has been eclipsed by the blockbusters AIDS, tuberculosis, and malaria ("because of the availability of an HBV vaccine"), with concomitant political inertia in combatting HBV. HCC research has been 
chronically and grossly underfunded on the subcontinent, with research being performed mainly by research groups in high-income settings. Without a doubt, the COVID-19 pandemic will further aggravate the situation, leading to HCC in SSA being side-lined and neglected, contributing to high morbidity and mortality, especially in the younger age groups.

Changes in the population demographics and prevalence of HCC-related risk factors will dictate the temporal trends in epidemiology of this malignancy in the coming decades. The decline of HBV as a risk factor for HCC may be offset by the emergence of NAFLD and ageing as risk factors for HCC development. Indeed, future prospective cohort studies are required to confirm this. The wider adoption of imaging diagnostic modalities and population-based cancer registries are required to provide reliable data to determine the true incidence of HCC, which is currently underestimated. This will permit clinicians and public policy makers to anticipate and adapt accordingly in terms of public health perspectives, resource allocation and formulation of management guidelines specific for Sub-Saharan African patients with HCC. There is still much work to be done to reduce the burden of this cancer on the subcontinent.

\section{DECLARATIONS}

\section{Authors' contributions}

Writing and preparation of original draft as part of his $\mathrm{PhD}$ thesis, preparation of figures: Mak D

Conceptualisation, resources, review and editing of original draft, synthesis and discussion to yield the finalized version, supervision and financial support of student: Kramvis A

\section{Availability of data and materials}

Not applicable.

\section{Financial support and sponsorship}

Cancer Association of South Africa (CANSA), and German Research Foundation (Deutsche Forschungsgemeinschaft).

\section{Conflicts of interest}

All authors declared that there are no conflicts of interest.

\section{Ethical approval and consent to participate}

Not applicable.

\section{Consent for publication}

Not applicable.

\section{Copyright}

(c) The Author(s) 2021.

\section{REFERENCES}

1. Bray F, Ferlay J, Soerjomataram I, Siegel RL, Torre LA, Jemal A. Global cancer statistics 2018: GLOBOCAN estimates of incidence and mortality worldwide for 36 cancers in 185 countries. CA Cancer J Clin 2018;68:394-424. DOI PubMed

2. Ferlay J, Ervik M, Lam F, et al. Global Cancer Observatory: Cancer Today. Lyon, France: International Agency for Research on Cancer. Available from: https://gco.iarc.fr/ [Last accessed on 8 May 2021].

3. United Nations DoEaSA. Population Division World Population Prospects 2019. Available from: https://population.un.org/wpp/. [Last accessed on 20 Apr 2021].

4. Shoup JA. Ethnic Groups of Africa and the Middle East: An Encyclopedia. Santa Barbara, California: ABC-CLIO; 2011.

5. Parkin DM, Bray F, Ferlay J, Pisani P. Global cancer statistics, 2002. CA Cancer J Clin 2005;55:74-108. DOI PubMed

6. Ananthakrishnan A, Gogineni V, Saeian K. Epidemiology of primary and secondary liver cancers. Semin Intervent Radiol 2006;23:47-63. DOI PubMed PMC 
7. Altekruse SF, McGlynn KA, Reichman ME. Hepatocellular carcinoma incidence, mortality, and survival trends in the United States from 1975 to 2005. J Clin Oncol 2009;27:1485-91. DOI PubMed PMC

8. Banales JM, Marin JJG, Lamarca A, et al. Cholangiocarcinoma 2020: the next horizon in mechanisms and management. Nat Rev Gastroenterol Hepatol 2020;17:557-88. DOI PubMed PMC

9. Sia D, Villanueva A, Friedman SL, Llovet JM. Liver Cancer Cell of Origin, Molecular Class, and Effects on Patient Prognosis. Gastroenterology 2017;152:745-61. DOI PubMed

10. Asombang AW, Chishinga N, Nkhoma A, et al. A Systematic Review of Cholangiocarcinoma in Africa: Epidemiology, Management and Clinical Outcomes. Am J Gastroenterol 2020;115:S13. DOI

11. Ferlay J, Shin HR, Bray F, Forman D, Mathers C, Parkin DM. Estimates of worldwide burden of cancer in 2008: GLOBOCAN 2008. Int $J$ Cancer 2010;127:2893-917. DOI PubMed

12. Ferlay J, Soerjomataram I, Dikshit R, et al. Cancer incidence and mortality worldwide: sources, methods and major patterns in GLOBOCAN 2012. Int J Cancer 2015;136:E359-86. DOI PubMed

13. Ferlay J, Soerjomataram I, Ervik M, et al. GLOBOCAN 2012: Estimated Cancer Incidence, Mortality and Prevalence Worldwide in 2012 v1.0. IARC CancerBase No. 11. Available from: https://publications.iarc.fr/Databases/Iarc-Cancerbases/GLOBOCAN-2012Estimated-Cancer-Incidence-Mortality-And-Prevalence-Worldwide-In-2012-V1.0-2012. [Last accessed on 20 Apr 2021].

14. Kew MC. Epidemiology of hepatocellular carcinoma in sub-Saharan Africa. Ann Hepatol 2013;12:173-82. PubMed

15. Ekanem IO, Parkin DM. Five year cancer incidence in Calabar, Nigeria (2009-2013). Cancer Epidemiol 2016;42:167-72. DOI PubMed

16. Wabinga HR, Nambooze S, Amulen PM, Okello C, Mbus L, Parkin DM. Trends in the incidence of cancer in Kampala, Uganda 1991-2010. Int J Cancer 2014;135:432-9. DOI PubMed

17. Somdyala NI, Parkin DM, Sithole N, Bradshaw D. Trends in cancer incidence in rural Eastern Cape Province; South Africa, 19982012. Int J Cancer 2015;136:E470-4. DOI PubMed

18. Chokunonga E, Borok MZ, Chirenje ZM, Nyakabau AM, Parkin DM. Trends in the incidence of cancer in the black population of Harare, Zimbabwe 1991-2010. Int J Cancer 2013;133:721-9. DOI PubMed

19. Bah E, Carrieri MP, Hainaut P, Bah Y, Nyan O, Taal M. 20-years of population-based cancer registration in hepatitis B and liver cancer prevention in the Gambia, West Africa. PLoS One 2013;8:e75775. DOI PubMed PMC

20. Ashta A. A minimum wage solution to halving world poverty by 2015: A stakeholder approach. IIMB Management Review 2013;25:6-18. DOI

21. Islami F, Miller KD, Siegel RL, Fedewa SA, Ward EM, Jemal A. Disparities in liver cancer occurrence in the United States by race/ethnicity and state. CA Cancer J Clin 2017;67:273-89. DOI PubMed

22. Mak D, Babb de Villiers C, Chasela C, Urban MI, Kramvis A. Analysis of risk factors associated with hepatocellular carcinoma in black South Africans: 2000-2012. PLoS One 2018;13:e0196057. DOI PubMed PMC

23. Cancer Surveillance. In: Cancer Atlas. Atlantic: American Cancer Society; 2019. p. 33.

24. Sartorius K, Sartorius B, Aldous C, Govender PS, Madiba TE. Global and country underestimation of hepatocellular carcinoma (HCC) in 2012 and its implications. Cancer Epidemiol 2015;39:284-90. DOI PubMed

25. Xu L, Kim Y, Spolverato G, Gani F, Pawlik TM. Racial disparities in treatment and survival of patients with hepatocellular carcinoma in the United States. Hepatobiliary Surg Nutr 2016;5:43-52. DOI PubMed PMC

26. Allemani C, Weir HK, Carreira H, et al. Global surveillance of cancer survival 1995-2009: analysis of individual data for 25676887 patients from 279 population-based registries in 67 countries (CONCORD-2). Lancet 2015;385:977-1010. DOI PubMed PMC

27. Sankaranarayanan R. Cancer survival in Africa, Asia, the Caribbean and Central America. Introduction. IARC Sci Publ 2011;(162):15. PubMed

28. Yang JD, Mohamed EA, Aziz AOA, et al. Characteristics, management, and outcomes of patients with hepatocellular carcinoma in Africa: a multicountry observational study from the Africa Liver Cancer Consortium. Lancet Gastroenterol Hepatol 2017;2:103-11. DOI PubMed

29. Kew MC. Clinical, pathologic, and etiologic heterogeneity in hepatocellular carcinoma: evidence from southern Africa. Hepatology 1981;1:366-9. DOI PubMed

30. Lemoine M, Thursz MR. Battlefield against hepatitis B infection and HCC in Africa. J Hepatol 2017;66:645-54. DOI PubMed

31. Gondos A, Brenner H, Wabinga H, Parkin DM. Cancer survival in Kampala, Uganda. Br J Cancer 2005;92:1808-12. DOI PubMed PMC

32. Bah E, Sam O, Whittle H, Ramanakumar A, Sankaranarayanan R. Cancer survival in the Gambia, 1993-1997. IARC Sci Publ 2011;(162):97-100. PubMed

33. Montomoli J, Erichsen R, Nørgaard M, Høyer M, Hansen JB, Jacobsen JB. Survival of patients with primary liver cancer in central and northern Denmark, 1998-2009. Clin Epidemiol 2011;3 Suppl 1:3-10. DOI PubMed PMC

34. Momin BR, Pinheiro PS, Carreira H, Li C, Weir HK. Liver cancer survival in the United States by race and stage (2001-2009): findings from the CONCORD-2 study. Cancer 2017;123 Suppl 24:5059-78. DOI PubMed PMC

35. Mak D, Sengayi M, Chen WC, Babb de Villiers C, Singh E, Kramvis A. Liver cancer mortality trends in South Africa: 1999-2015. BMC Cancer 2018;18:798. DOI PubMed PMC

36. Sloane D, Chen H, Howell C. Racial disparity in primary hepatocellular carcinoma: tumor stage at presentation, surgical treatment and survival. J Natl Med Assoc 2006;98:1934-9. PubMed PMC

37. Flores YN, Yee HF Jr, Leng M, et al. Risk factors for chronic liver disease in Blacks, Mexican Americans, and Whites in the United States: results from NHANES IV, 1999-2004. Am J Gastroenterol 2008;103:2231-8. DOI PubMed PMC 
38. Singh GK, Jemal A. Socioeconomic and Racial/Ethnic Disparities in Cancer Mortality, Incidence, and Survival in the United States, 1950-2014: Over Six Decades of Changing Patterns and Widening Inequalities. J Environ Public Health 2017;2017:2819372. DOI PubMed PMC

39. Yang JD, Gyedu A, Afihene MY, et al; Africa Network for Gastrointestinal and Liver Diseases. Hepatocellular Carcinoma Occurs at an Earlier Age in Africans, Particularly in Association With Chronic Hepatitis B. Am J Gastroenterol 2015;110:1629-31. DOI PubMed

40. McGlynn KA, Tarone RE, El-Serag HB. A comparison of trends in the incidence of hepatocellular carcinoma and intrahepatic cholangiocarcinoma in the United States. Cancer Epidemiol Biomarkers Prev 2006;15:1198-203. DOI PubMed

41. Shimakawa Y, Lemoine M. Early age at diagnosis of hepatocellular carcinoma in sub-Saharan Africa. Lancet Gastroenterol Hepatol 2017;2:393. DOI PubMed

42. Shimakawa Y, Lemoine M, Njai HF, et al. Natural history of chronic HBV infection in West Africa: a longitudinal population-based study from The Gambia. Gut 2016;65:2007-16. DOI PubMed

43. Ladep NG, Lesi OA, Mark P, et al. Problem of hepatocellular carcinoma in West Africa. World J Hepatol 2014;6:783-92. DOI PubMed PMC

44. Kew MC. Hepatocellular carcinoma in sub-Saharan Africa. Trafford Publishing 2012.

45. Kramvis A. Challenges for hepatitis B virus cure in resource-limited settings in sub-Saharan Africa. Curr Opin HIV AIDS 2020;15:185-92. DOI PubMed

46. Yu MC, Yuan JM. Environmental factors and risk for hepatocellular carcinoma. Gastroenterology 2004;127:S72-8. DOI PubMed

47. Corte C, Aghemo A, Colombo M. Individualized hepatocellular carcinoma risk: the challenges for designing successful chemoprevention strategies. World J Gastroenterol 2013;19:1359-71. DOI PubMed PMC

48. Villanueva A, Luedde T. The transition from inflammation to cancer in the liver. Clin Liver Dis (Hoboken) 2016;8:89-93. DOI PubMed PMC

49. Fattovich G, Stroffolini T, Zagni I, Donato F. Hepatocellular carcinoma in cirrhosis: incidence and risk factors. Gastroenterology 2004;127:S35-50. DOI PubMed

50. Kumar A, Riely CA. Inherited liver diseases in adults. West J Med 1995;163:382-6. PubMed PMC

51. Bralet MP, Régimbeau JM, Pineau P, et al. Hepatocellular carcinoma occurring in nonfibrotic liver: epidemiologic and histopathologic analysis of 80 French cases. Hepatology 2000;32:200-4. DOI PubMed

52. Young AL, Adair R, Prasad KR, Toogood GJ, Lodge JP. Hepatocellular carcinoma within a noncirrhotic, nonfibrotic, seronegative liver: surgical approaches and outcomes. J Am Coll Surg 2012;214:174-83. DOI PubMed

53. Mittal S, El-Serag HB, Sada YH, et al. Hepatocellular Carcinoma in the absence of cirrhosis in United States veterans is associated with Nonalcoholic Fatty Liver disease. Clin Gastroenterol Hepatol 2016;14:124-31.e1. DOI PubMed PMC

54. Schlageter M, Terracciano LM, D’Angelo S, Sorrentino P. Histopathology of hepatocellular carcinoma. World J Gastroenterol 2014;20:15955-64. DOI PubMed PMC

55. Nzeako UC, Goodman ZD, Ishak KG. Hepatocellular carcinoma in cirrhotic and noncirrhotic livers. A clinico-histopathologic study of 804 North American patients. Am J Clin Pathol 1996;105:65-75. DOI PubMed

56. Schütte K, Schulz C, Poranzke J, et al. Characterization and prognosis of patients with hepatocellular carcinoma (HCC) in the noncirrhotic liver. BMC Gastroenterol 2014;14:117. DOI PubMed PMC

57. Evert M, Dombrowski F. [Hepatocellular carcinoma in the non-cirrhotic liver]. Pathologe 2008;29:47-52. DOI PubMed

58. Kew MC. Hepatocellular carcinoma with and without cirrhosis. Gastroenterology 1989;97:136-9. DOI PubMed

59. Chayanupatkul M, Omino R, Mittal S, et al. Hepatocellular carcinoma in the absence of cirrhosis in patients with chronic hepatitis B virus infection. J Hepatol 2017;66:355-62. DOI PubMed

60. Kew MC. The role of cirrhosis in the etiology of hepatocellular carcinoma. J Gastrointest Cancer 2014;45:12-21. DOI PubMed

61. Schulze K, Imbeaud S, Letouzé E, et al. Exome sequencing of hepatocellular carcinomas identifies new mutational signatures and potential therapeutic targets. Nat Genet 2015;47:505-11. DOI PubMed PMC

62. Llovet JM, Kelley RK, Villanueva A, et al. Hepatocellular carcinoma. Nat Rev Dis Primers 2021;7:6. DOI PubMed

63. Caruso S, O'Brien DR, Cleary SP, Roberts LR, Zucman-Rossi J. Genetics of Hepatocellular Carcinoma: Approaches to Explore Molecular Diversity. Hepatology 2021;73 Suppl 1:14-26. DOI PubMed

64. Genome Atlas Research Network. Electronic address: wheeler@bcm.edu., Cancer Genome Atlas Research Network. Comprehensive and Integrative Genomic Characterization of Hepatocellular Carcinoma. Cell 2017;169:1327-1341.e23. DOI PubMed PMC

65. Calderaro J, Ziol M, Paradis V, Zucman-Rossi J. Molecular and histological correlations in liver cancer. J Hepatol 2019;71:616-30. DOI PubMed

66. Désert R, Nieto N, Musso O. Dimensions of hepatocellular carcinoma phenotypic diversity. World J Gastroenterol 2018;24:4536-47. DOI PubMed PMC

67. Zucman-Rossi J, Villanueva A, Nault JC, Llovet JM. Genetic Landscape and Biomarkers of Hepatocellular Carcinoma. Gastroenterology 2015;149:1226-1239.e4. DOI PubMed

68. Chiang DY, Villanueva A. Progress towards molecular patient stratification of hepatocellular carcinoma: Lost in translation? $J$ Hepatol 2017;67:893-5. DOI PubMed

69. Cerapio JP, Marchio A, Cano L, et al. Global DNA hypermethylation pattern and unique gene expression signature in liver cancer from patients with Indigenous American ancestry. Oncotarget 2021;12:475-92. DOI PubMed PMC

70. Marchio A, Cerapio JP, Ruiz E, et al. Early-onset liver cancer in South America associates with low hepatitis B virus DNA burden. Sci Rep 2018;8:12031. DOI PubMed PMC 
71. Kew MC, Kramvis A, Yu MC, Arakawa K, Hodkinson J. Increased hepatocarcinogenic potential of hepatitis B virus genotype A in Bantu-speaking sub-saharan Africans. J Med Virol 2005;75:513-21. DOI PubMed

72. Tanaka Y, Hasegawa I, Kato T, et al. A case-control study for differences among hepatitis B virus infections of genotypes A (subtypes Aa and Ae) and D. Hepatology 2004;40:747-55. DOI PubMed

73. Martel C, Maucort-Boulch D, Plummer M, Franceschi S. World-wide relative contribution of hepatitis B and C viruses in hepatocellular carcinoma. Hepatology 2015;62:1190-200. DOI PubMed PMC

74. Maucort-Boulch D, de Martel C, Franceschi S, Plummer M. Fraction and incidence of liver cancer attributable to hepatitis B and C viruses worldwide. Int J Cancer 2018;142:2471-7. DOI PubMed

75. Perz JF, Armstrong GL, Farrington LA, Hutin YJ, Bell BP. The contributions of hepatitis B virus and hepatitis C virus infections to cirrhosis and primary liver cancer worldwide. J Hepatol 2006;45:529-38. DOI PubMed

76. Raza SA, Clifford GM, Franceschi S. Worldwide variation in the relative importance of hepatitis B and hepatitis C viruses in hepatocellular carcinoma: a systematic review. Br J Cancer 2007;96:1127-34. DOI PubMed PMC

77. Parkin DM, Hämmerl L, Ferlay J, Kantelhardt EJ. Cancer in Africa 2018: The role of infections. Int J Cancer 2020;146:2089-103. DOI PubMed

78. Singal AG, Lampertico P, Nahon P. Epidemiology and surveillance for hepatocellular carcinoma: new trends. J Hepatol 2020;72:250-61. DOI PubMed PMC

79. Zeng Z. Human genes involved in hepatitis B virus infection. World J Gastroenterol 2014;20:7696-706. DOI PubMed PMC

80. World Health Organization. Hepatitis B Fact Sheet, 2017. Available from https://www.who.int/news-room/factsheets/detail/hepatitis-b. [Last accessed on 7 May 2021].

81. El-Serag HB. Epidemiology of viral hepatitis and hepatocellular carcinoma. Gastroenterology 2012;142:1264-73.e1. DOI PubMed PMC

82. Lavanchy D, Kane M. Global Epidemiology of Hepatitis V Virus Infection. In: Molecular and Translational Medicine; 2016. p. 187203.

83. Schweitzer A, Horn J, Mikolajczyk RT, Krause G, Ott JJ. Estimations of worldwide prevalence of chronic hepatitis B virus infection: a systematic review of data published between 1965 and 2013. Lancet 2015;386:1546-55. DOI PubMed

84. Kiire C. Hepatitis B infection in sub-Saharan Africa. Vaccine 1990;8:S107-12. DOI PubMed

85. Kramvis A, Kew MC. Epidemiology of hepatitis B virus in Africa, its genotypes and clinical associations of genotypes. Hepatol Res 2007;37:S9-S19. DOI PubMed

86. Razavi-shearer D, Gamkrelidze I, Nguyen MH, et al. Global prevalence, treatment, and prevention of hepatitis B virus infection in 2016: a modelling study. Lancet Gastroenterol Hepatol 2018;3:383-403. DOI PubMed

87. Ott JJ, Stevens GA, Groeger J, Wiersma ST. Global epidemiology of hepatitis B virus infection: new estimates of age-specific HBsAg seroprevalence and endemicity. Vaccine 2012;30:2212-9. DOI PubMed

88. Kolou M, Katawa G, Salou M, et al. High Prevalence of Hepatitis B Virus Infection in the Age Range of 20-39 Years Old Individuals in Lome. Open Virol J 2017;11:1-7. DOI PubMed PMC

89. Kew MC. Hepatocellular carcinoma in African Blacks: Recent progress in etiology and pathogenesis. World J Hepatol 2010;2:65-73. DOI PubMed PMC

90. Binka M, Butt ZA, Wong S, et al. Differing profiles of people diagnosed with acute and chronic hepatitis B virus infection in British Columbia, Canada. World J Gastroenterol 2018;24:1216-27. DOI PubMed PMC

91. Elgouhari HM, Abu-Rajab Tamimi TI, Carey WD. Hepatitis B virus infection: understanding its epidemiology, course, and diagnosis. Cleve Clin J Med 2008;75:881-9. DOI PubMed

92. Edmunds WJ, Medley GF, Nokes DJ, O'Callaghan CJ, Whittle HC, Hall AJ. Epidemiological patterns of hepatitis B virus (HBV) in highly endemic areas. Epidemiol Infect 1996;117:313-25. DOI PubMed PMC

93. Burnett RJ, Kramvis A, Dochez C, Meheus A. An update after 16 years of hepatitis B vaccination in South Africa. Vaccine 2012;30 Suppl 3:C45-51. DOI PubMed

94. Simonsen L, Kane A, Lloyd J, Zaffran M, Kane M. Unsafe injections in the developing world and transmission of bloodborne pathogens: a review. Bull World Health Organ 1999;77:789-800. PubMed PMC

95. Shimakawa Y, Lemoine M, Bottomley C, et al. Birth order and risk of hepatocellular carcinoma in chronic carriers of hepatitis B virus: a case-control study in The Gambia. Liver Int 2015;35:2318-26. DOI PubMed

96. Thompson SC. Perinatal transmission of hepatitis B virus: an Australian experience. Med J Aust 2009;191:357; author reply 357. DOI PubMed

97. Kramvis A. The clinical implications of hepatitis B virus genotypes and HBeAg in pediatrics. Rev Med Virol 2016;26:285-303. DOI PubMed PMC

98. Musa BM, Bussell S, Borodo MM, Samaila AA, Femi OL. Prevalence of hepatitis B virus infection in Nigeria, 2000-2013: a systematic review and meta-analysis. Niger J Clin Pract 2015;18:163-72. DOI PubMed

99. Coursaget P, Leboulleux D, Yvonnet B, et al. Hepatitis B virus infection and hepatocellular carcinoma in Senegal: prevalence and prevention. J Gastroenterol Hepatol 1993;8(S1):S128-33.

100. Mdlalose N, Parboosing R, Moodley P. The prevalence of hepatitis B virus infection in HIV-positive and HIV-negative infants: KwaZulu-Natal, South Africa. Afr J Lab Med 2016;5:283. DOI PubMed PMC

101. Vardas E, Mathai M, Blaauw D, McAnerney J, Coppin A, Sim J. Preimmunization epidemiology of hepatitis B virus infection in South African children. J Med Virol 1999;58:111-5. PubMed

102. Kew M, Houghton M, Choo Q, Kuo G. Hepatitis C virus antibodies in southern African blacks with hepatocellular carcinoma. Lancet 
1990;335:873-4. DOI PubMed

103. Kew MC. Hepatitis B virus infection: the burden of disease in South Africa. Southern African Journal of Epidemiology and Infection 2015;23:4-8.

104. Kew MC, Rossouw E, Hodkinson J, Paterson A, Dusheiko GM, Whitcutt JM. Hepatitis B virus status of southern African Blacks with hepatocellular carcinoma: comparison between rural and urban patients. Hepatology 1983;3:65-8. DOI PubMed

105. Liu TT, Fang Y, Xiong H, et al. A case-control study of the relationship between hepatitis B virus DNA level and risk of hepatocellular carcinoma in Qidong, China. World J Gastroenterol 2008;14:3059-63. DOI PubMed PMC

106. Kew MC, Kassianides C, Hodkinson J, Coppin A, Paterson AC. Hepatocellular carcinoma in urban born blacks: frequency and relation to hepatitis B virus infection. Br Med J 293:1339-41. DOI PubMed PMC

107. Kew MC. Synergistic interaction between aflatoxin B1 and hepatitis B virus in hepatocarcinogenesis. Liver Int 2003;23:405-9. DOI PubMed

108. Kew MC. Hepatic iron overload and hepatocellular carcinoma. Cancer Lett 2009;286:38-43. DOI PubMed

109. Chen G, Lin W, Shen F, Iloeje UH, London WT, Evans AA. Past HBV viral load as predictor of mortality and morbidity from HCC and chronic liver disease in a prospective study. Am J Gastroenterol 2006;101:1797-803. DOI PubMed

110. Tang B, Kruger WD, Chen G, et al. Hepatitis B viremia is associated with increased risk of hepatocellular carcinoma in chronic carriers. J Med Virol 2004;72:35-40. DOI PubMed

111. Viana R, Wang R, Yu MC, Welschinger R, Chen CY, Kew MC. Hepatitis B viral loads in southern African Blacks with hepatocellular carcinoma. J Med Virol 2009;81:1525-30. DOI PubMed

112. Yousif M, Mudawi H, Bakhiet S, Glebe D, Kramvis A. Molecular characterization of hepatitis B virus in liver disease patients and asymptomatic carriers of the virus in Sudan. BMC Infect Dis 2013;13:328. DOI PubMed PMC

113. Ochwoto M, Chauhan R, Gopalakrishnan D, et al. Genotyping and molecular characterization of hepatitis B virus in liver disease patients in Kenya. Infect Genet Evol 2013;20:103-10. DOI PubMed

114. Mendy ME, Welzel T, Lesi OA, et al. Hepatitis B viral load and risk for liver cirrhosis and hepatocellular carcinoma in The Gambia, West Africa. J Viral Hepat 2010;17:115-22. DOI PubMed PMC

115. Kramvis A. Molecular characteristics and clinical relevance of African genotypes and subgenotypes of hepatitis B virus. S Afr Med J 2018;108:17-21. DOI PubMed

116. Lereau M, Gouas D, Villar S, et al. Interactions between hepatitis B virus and aflatoxin B(1): effects on p53 induction in HepaRG cells. J Gen Virol 2012;93:640-50. DOI PubMed

117. Rensburg SJ, Cook-Mozaffari P, Van Schalkwyk DJ, Van der Watt JJ, Vincent TJ, Purchase IF. Hepatocellular carcinoma and dietary aflatoxin in Mozambique and Transkei. Br J Cancer 1985;51:713-26. DOI PubMed PMC

118. Viljoen JH. Mycotoxins in grain and grain products in South Africa and proposals for their regulation. University of Pretoria, 2003. Available from: https://repository.up.ac.za/bitstream/handle/2263/27846/Complete.pdf?sequence=8. [Last accessed on 20 Apr 2021].

119. Lun-Gen L. Antiviral Therapy of Liver Cirrhosis Related to Hepatitis B Virus Infection. J Clin Transl Hepatol 2014;2:197-201. DOI PubMed PMC

120. Raimondo G, Allain JP, Brunetto MR, et al. Statements from the Taormina expert meeting on occult hepatitis B virus infection. $J$ Hepatol 2008;49:652-7. DOI PubMed

121. Raimondo G, Locarnini S, Pollicino T, Levrero M, Zoulim F, Lok AS; Taormina Workshop on Occult HBV Infection Faculty Members. Update of the statements on biology and clinical impact of occult hepatitis B virus infection. J Hepatol 2019;71:397-408. DOI PubMed

122. Pollicino T, Squadrito G, Cerenzia G, et al. Hepatitis B virus maintains its pro-oncogenic properties in the case of occult HBV infection. Gastroenterology 2004;126:102-10. DOI PubMed

123. Saitta C, Tripodi G, Barbera A, et al. Hepatitis B virus (HBV) DNA integration in patients with occult HBV infection and hepatocellular carcinoma. Liver Int 2015;35:2311-7. DOI PubMed

124. Kew MC, Welschinger R, Viana R. Occult hepatitis B virus infection in Southern African blacks with hepatocellular carcinoma. $J$ Gastroenterol Hepatol 2008;23:1426-30. DOI PubMed

125. Shi Y, Wu YH, Wu W, Zhang WJ, Yang J, Chen Z. Association between occult hepatitis B infection and the risk of hepatocellular carcinoma: a meta-analysis. Liver Int 2012;32:231-40. DOI PubMed

126. Bruzzi P, Green SB, Byar DP, Brinton LA, Schairer C. Estimating the population attributable risk for multiple risk factors using casecontrol data. Am J Epidemiol 1985;122:904-14. DOI PubMed

127. Kramvis A. Genotypes and genetic variability of hepatitis B virus. Intervirology 2014;57:141-50. DOI PubMed

128. Kramvis A, Kew MC. Relationship of genotypes of hepatitis B virus to mutations, disease progression and response to antiviral therapy. J Viral Hepat 2005;12:456-64. DOI PubMed

129. Mak D, Kramvis A. Molecular characterization of hepatitis B virus isolated from Black South African cancer patients, with and without hepatocellular carcinoma. Arch Virol 2020;165:1815-25. DOI PubMed

130. Baptista M, Kramvis A, Kew MC. High prevalence of 1762(T) 1764(A) mutations in the basic core promoter of hepatitis B virus isolated from black Africans with hepatocellular carcinoma compared with asymptomatic carriers. Hepatology 1999;29:946-53. DOI PubMed

131. Cohen D, Ghosh S, Shimakawa Y, et al. Hepatitis B virus preS2 $\triangle 38-55$ variants: A newly identified risk factor for hepatocellular carcinoma. JHEP Rep 2020;2:100144. DOI PubMed PMC

132. Li KW, Kramvis A, Liang S, et al. Higher prevalence of cancer related mutations 1762T/1764A and PreS deletions in hepatitis B virus (HBV) isolated from HBV/HIV co-infected compared to HBV-mono-infected Chinese adults. Virus Res 2017;227:88-95. DOI 
PubMed

133. Fang ZL, Sabin CA, Dong BQ, et al. HBV A1762T, G1764A mutations are a valuable biomarker for identifying a subset of male HBsAg carriers at extremely high risk of hepatocellular carcinoma: a prospective study. Am J Gastroenterol 2008;103:2254-62. DOI PubMed PMC

134. Taylor JM. Chapter 3 Replication of the hepatitis delta virus RNA genome. Adv Virus Res 2009;74:103-21. DOI PubMed

135. Rizzetto M, Shih JW, Gerin JL. The hepatitis B virus-associated delta antigen: isolation from liver, development of solid-phase radioimmunoassays for delta antigen and anti-delta and partial characterization of delta antigen. J Immunol 1980;125:318-24. PubMed

136. Rizzetto M. Hepatitis D Virus: Introduction and Epidemiology. Cold Spring Harb Perspect Med 2015;5:a021576. DOI PubMed PMC

137. Stockdale AJ, Kreuels B, Henrion MYR, et al. The global prevalence of hepatitis D virus infection: Systematic review and metaanalysis. J Hepatol 2020;73:523-32. DOI PubMed PMC

138. Chen HY, Shen DT, Ji DZ, et al. Prevalence and burden of hepatitis D virus infection in the global population: a systematic review and meta-analysis. Gut 2019;68:512-21. DOI PubMed

139. Stockdale AJ, Kreuels B, Henrion MRY, Giorgi E, Kyomuhangi I, Geretti AM. Hepatitis D prevalence: problems with extrapolation to global population estimates. Gut 2020;69:396-7. DOI PubMed

140. Sagnelli C, Sagnelli E, Russo A, Pisaturo M, Occhiello L, Coppola N. HBV/HDV Co-Infection: Epidemiological and Clinical Changes, Recent Knowledge and Future Challenges. Life (Basel) 2021;11:169. DOI PubMed PMC

141. Gal F, Brichler S, Sahli R, Chevret S, Gordien E. First international external quality assessment for hepatitis delta virus RNA quantification in plasma. Hepatology 2016;64:1483-94. DOI PubMed

142. Stockdale AJ, Chaponda M, Beloukas A, et al. Prevalence of hepatitis D virus infection in sub-Saharan Africa: a systematic review and meta-analysis. Lancet Glob Health 2017;5:e992-e1003. DOI PubMed PMC

143. Lunel-Fabiani F, Mansour W, Amar AO, et al. Impact of hepatitis B and delta virus co-infection on liver disease in Mauritania: a cross sectional study. J Infect 2013;67:448-57. DOI PubMed

144. Mbaye PS, Renaudineau Y, Diallo A, et al. Virus de l'hépatite C et hépatopathies chroniques à Dakar: étude cas-témoins [Hepatitis C virus and chronic hepatopathies in Dakar: case-control study]. Med Trop (Mars) 2000;60:47-52. (in French). PubMed

145. Asmah RH, Boamah I, Afodzinu M, et al. Prevalence of hepatitis d infection in patients with hepatitis B virus-related liver diseases in Accra, Ghana. West Afr J Med 2014;33:32-6. PubMed

146. Amougou MA, Noah DN, Moundipa PF, Pineau P, Njouom R. A prominent role of hepatitis D virus in liver cancers documented in Central Africa. BMC Infect Dis 2016;16:647. DOI PubMed PMC

147. Tuaillon E, Kania D, Gordien E, Van de Perre P, Dujols P. Epidemiological data for hepatitis D in Africa. Lancet Glob Health 2018;6:e33. DOI PubMed

148. Petruzziello A, Marigliano S, Loquercio G, Cozzolino A, Cacciapuoti C. Global epidemiology of hepatitis C virus infection: An update of the distribution and circulation of hepatitis C virus genotypes. World J Gastroenterol 2016;22:7824-40. DOI PubMed PMC

149. Simmonds P, Becher P, Bukh J, et al. ICTV Virus Taxonomy Profile: Flaviviridae. J Gen Virol 2017;98:2-3. DOI PubMed PMC

150. Smith DB, Bukh J, Kuiken C, et al. Expanded classification of hepatitis C virus into 7 genotypes and 67 subtypes: updated criteria and genotype assignment web resource. Hepatology 2014;59:318-27. DOI PubMed PMC

151. Borgia SM, Hedskog C, Parhy B, et al. Identification of a Novel Hepatitis C Virus Genotype From Punjab, India: Expanding Classification of Hepatitis C Virus Into 8 Genotypes. J Infect Dis 2018;218:1722-9. DOI PubMed

152. Magiorkinis G, Magiorkinis E, Paraskevis D, et al. The global spread of hepatitis C virus 1a and 1b: a phylodynamic and phylogeographic analysis. PLoS Med 2009;6:e1000198. DOI PubMed PMC

153. Smith DB, Pathirana S, Davidson F, et al. The origin of hepatitis C virus genotypes. J Gen Virol 1997;78 (Pt 2):321-8. DOI PubMed

154. Pybus OG, Cochrane A, Holmes EC, Simmonds P. The hepatitis C virus epidemic among injecting drug users. Infect Genet Evol 2005;5:131-9. DOI PubMed

155. Messina JP, Humphreys I, Flaxman A, et al. Global distribution and prevalence of hepatitis C virus genotypes. Hepatology 2015;61:77-87. DOI PubMed PMC

156. Murphy DG, Sablon E, Chamberland J, Fournier E, Dandavino R, Tremblay CL. Hepatitis C virus genotype 7, a new genotype originating from central Africa. J Clin Microbiol 2015;53:967-72. DOI PubMed PMC

157. Salmona M, Caporossi A, Simmonds P, et al. First next-generation sequencing full-genome characterization of a hepatitis $C$ virus genotype 7 divergent subtype. Clin Microbiol Infect 2016;22:947.e1-8. DOI PubMed

158. Amougou-Atsama M, Jean Adrien Atangana P, Noah Noah D, Fewou Moundipa P, Pineau P, Njouom R. The role of hepatitis C virus genotypes and core mutations in hepatocellular carcinoma in Cameroon. J Viral Hepat 2020;27:880-5. DOI PubMed

159. Tanaka Y, Kurbanov F, Mano S, et al. Molecular tracing of the global hepatitis C virus epidemic predicts regional patterns of hepatocellular carcinoma mortality. Gastroenterology 2006;130:703-14. DOI PubMed

160. Riou J, Ait Ahmed M, Blake A, et al; HCV epidemiology in Africa group. Hepatitis C virus seroprevalence in adults in Africa: a systematic review and meta-analysis. J Viral Hepat 2016;23:244-55. DOI PubMed

161. Okeke E, Davwar PM, Roberts L, et al. Epidemiology of Liver Cancer in Africa: Current and Future Trends. Semin Liver Dis 2020;40:111-23. DOI PubMed

162. Donato F, Boffetta P, Puoti M. A meta-analysis of epidemiological studies on the combined effect of hepatitis B and C virus infections in causing hepatocellular carcinoma. Int J Cancer 1998;75:347-54. DOI PubMed

163. Thein HH, Yi Q, Dore GJ, Krahn MD. Estimation of stage-specific fibrosis progression rates in chronic hepatitis C virus infection: a 
meta-analysis and meta-regression. Hepatology 2008;48:418-31. DOI PubMed

164. Thrift AP, El-Serag HB, Kanwal F. Global epidemiology and burden of HCV infection and HCV-related disease. Nat Rev Gastroenterol Hepatol 2017;14:122-32. DOI PubMed

165. Freeman AJ, Dore GJ, Law MG, et al. Estimating progression to cirrhosis in chronic hepatitis C virus infection. Hepatology 2001;34:809-16. DOI PubMed

166. Mallat A, Hezode C, Lotersztajn S. Environmental factors as disease accelerators during chronic hepatitis C. J Hepatol 2008;48:65765. DOI PubMed

167. Liu Y, Wu F. Global burden of aflatoxin-induced hepatocellular carcinoma: a risk assessment. Environ Health Perspect 2010;118:818-24. DOI PubMed PMC

168. Huang YW, Yang SS, Fu SC, et al. Increased risk of cirrhosis and its decompensation in chronic hepatitis C patients with new-onset diabetes: a nationwide cohort study. Hepatology 2014;60:807-14. DOI PubMed

169. Rao H, Wu E, Fu S, et al. The higher prevalence of truncal obesity and diabetes in American than Chinese patients with chronic hepatitis C might contribute to more rapid progression to advanced liver disease. Aliment Pharmacol Ther 2017;46:731-40. DOI PubMed

170. Chen JY, Feeney ER, Chung RT. HCV and HIV co-infection: mechanisms and management. Nat Rev Gastroenterol Hepatol 2014;11:362-71. DOI PubMed PMC

171. Zampino R, Pisaturo MA, Cirillo G, et al. Hepatocellular carcinoma in chronic HBV-HCV co-infection is correlated to fibrosis and disease duration. Ann Hepatol 2015;14:75-82. PubMed

172. Cho EY, Choi CS, Cho JH, Kim HC. Association between Hepatitis B Virus X Gene Mutations and Clinical Status in Patients with Chronic Hepatitis B Infection. Gut Liver 2011;5:70-6. DOI PubMed PMC

173. Bukh J, Miller RH, Kew MC, Purcell RH. Hepatitis C virus RNA in southern African blacks with hepatocellular carcinoma. Proc Natl Acad Sci U S A 1993;90:1848-51. DOI PubMed PMC

174. Kew M, Yu M, Kedda M, Coppin A, Sarkin A, Hodkinson J. The relative roles of hepatitis B and C viruses in the etiology of hepatocellular carcinoma in southern African blacks. Gastroenterology 1997;112:184-7. DOI PubMed

175. El-Serag HB, Kramer J, Duan Z, Kanwal F. Racial differences in the progression to cirrhosis and hepatocellular carcinoma in HCVinfected veterans. Am J Gastroenterol 2014;109:1427-35. DOI PubMed

176. Mazumder PM, Sasmal D. Mycotoxins - limits and regulations. Anc Sci Life 2001;20:1-19. PubMed PMC

177. Hamid AS, Tesfamariam IG, Zhang Y, Zhang ZG. Aflatoxin B1-induced hepatocellular carcinoma in developing countries: Geographical distribution, mechanism of action and prevention. Oncol Lett 2013;5:1087-92. DOI PubMed PMC

178. Aguilar F, Hussain SP, Cerutti P. Aflatoxin B1 induces the transversion of G-->T in codon 249 of the p53 tumor suppressor gene in human hepatocytes. Proc Natl Acad Sci U S A 1993;90:8586-90. DOI PubMed PMC

179. Smela ME, Currier SS, Bailey EA, Essigmann JM. The chemistry and biology of aflatoxin B(1): from mutational spectrometry to carcinogenesis. Carcinogenesis 2001;22:535-45. DOI PubMed

180. Bressac B, Kew M, Wands J, Ozturk M. Selective G to T mutations of p53 gene in hepatocellular carcinoma from southern Africa. Nature 1991;350:429-31. DOI PubMed

181. Huang XH, Sun LH, Lu DD, et al. Codon 249 mutation in exon 7 of p53 gene in plasma DNA: maybe a new early diagnostic marker of hepatocellular carcinoma in Qidong risk area, China. World J Gastroenterol 2003;9:692-5. DOI PubMed PMC

182. Kirk GD, Camus-Randon AM, Mendy M, et al. Ser-249 p53 mutations in plasma DNA of patients with hepatocellular carcinoma from The Gambia. J Natl Cancer Inst 2000;92:148-53. DOI PubMed

183. Qian GS, Ross RK, Yu MC, et al. A follow-up study of urinary markers of aflatoxin exposure and liver cancer risk in Shanghai, People's Republic of China. Cancer Epidemiol Biomarkers Prev 1994;3:3-10. PubMed

184. Tang L, Xu L, Afriyie-Gyawu E, et al. Aflatoxin-albumin adducts and correlation with decreased serum levels of vitamins A and $\mathrm{E}$ in an adult Ghanaian population. Food Addit Contam Part A Chem Anal Control Expo Risk Assess 2009;26:108-18. DOI PubMed

185. Macé K, Aguilar F, Wang JS, et al. Aflatoxin B1-induced DNA adduct formation and p53 mutations in CYP450-expressing human liver cell lines. Carcinogenesis 1997;18:1291-7. DOI PubMed

186. Madden CR, Finegold MJ, Slagle BL. Altered DNA mutation spectrum in aflatoxin b1-treated transgenic mice that express the hepatitis B virus x protein. J Virol 2002;76:11770-4. DOI PubMed PMC

187. Merryweather-Clarke AT, Pointon JJ, Shearman JD, Robson KJ. Global prevalence of putative haemochromatosis mutations. J Med Genet 1997;34:275-8. DOI PubMed PMC

188. Beutler E, Gelbart T, West C, et al. Mutation analysis in hereditary hemochromatosis. Blood Cells Mol Dis 1996;22:187-94; discussion 194a. DOI PubMed

189. Bacon BR, Adams PC, Kowdley KV, Powell LW, Tavill AS; American Association for the Study of Liver Diseases. Diagnosis and management of hemochromatosis: 2011 practice guideline by the American Association for the Study of Liver Diseases. Hepatology 2011;54:328-43. DOI PubMed PMC

190. George D, Goldwurm S, Macdonald GA, et al. Increased hepatic iron concentration in nonalcoholic steatohepatitis is associated with increased fibrosis. Gastroenterology 1998;114:311-8. DOI PubMed

191. Bradbear RA, Bain C, Siskind V, Schofield FD, Webb S, Axelsen EM, Halliday JW, Bassett ML, Powell LW. Cohort study of internal malignancy in genetic hemochromatosis and other chronic nonalcoholic liver diseases. J Natl Cancer Inst 1985;75:81-4. PubMed

192. Strohmeyer G, Niederau C, Stremmel W. Survival and causes of death in hemochromatosis. Observations in 163 patients. Ann N Y Acad Sci 1988;526:245-57. DOI PubMed 
193. Elmberg M, Hultcrantz R, Ekbom A, et al. Cancer risk in patients with hereditary hemochromatosis and in their first-degree relatives. Gastroenterology 2003;125:1733-41. DOI PubMed

194. Nouedoui C, Biwole M, Singwe M, Ashutantang G, Mbakop A, Djoumessi S. Hemochromatose primitive dans un groupe de diabetiques noirs Africains a Yaounde, Cameroun. A propos de 8 observations [Primary hemochromatosis induced diabetes mellitus in 8 Black Africans in Yaounde, Cameroon]. Tunis Med 2003;81:205-8. (in French). PubMed

195. Mandishona E, MacPhail AP, Gordeuk VR, et al. Dietary iron overload as a risk factor for hepatocellular carcinoma in Black Africans. Hepatology 1998;27:1563-6. DOI PubMed

196. McLaren GD, Gordeuk VR. Hereditary hemochromatosis: insights from the Hemochromatosis and Iron Overload Screening (HEIRS) Study. Hematology Am Soc Hematol Educ Program 2009:195-206. DOI PubMed PMC

197. McNamara L, MacPhail AP, Gordeuk VR, Hasstedt SJ, Rouault T. Is there a link between African iron overload and the described mutations of the hereditary haemochromatosis gene? Br J Haematol 1998;102:1176-8. DOI PubMed

198. Kew MC, Asare GA. Dietary iron overload in the African and hepatocellular carcinoma. Liver Int 2007;27:735-41. DOI PubMed

199. Yun S, Vincelette ND. Update on iron metabolism and molecular perspective of common genetic and acquired disorder, hemochromatosis. Crit Rev Oncol Hematol 2015;95:12-25. DOI PubMed

200. Asare GA, Mossanda KS, Kew MC, Paterson AC, Kahler-Venter CP, Siziba K. Hepatocellular carcinoma caused by iron overload: a possible mechanism of direct hepatocarcinogenicity. Toxicology 2006;219:41-52. DOI PubMed

201. Asare GA, Paterson AC, Kew MC, Khan S, Mossanda KS. Iron-free neoplastic nodules and hepatocellular carcinoma without cirrhosis in Wistar rats fed a diet high in iron. J Pathol 2006;208:82-90. DOI PubMed

202. Fargion S, Valenti L, Fracanzani AL. Role of iron in hepatocellular carcinoma. Clin Liver Dis (Hoboken) 2014;3:108-10. DOI PubMed PMC

203. Gordeuk VR, McLaren CE, MacPhail AP, Deichsel G, Bothwell TH. Associations of iron overload in Africa with hepatocellular carcinoma and tuberculosis: Strachan's 1929 thesis revisited. Blood 1996;87:3470-6. PubMed

204. Moyo VM, Makunike R, Gangaidzo IT, et al. African iron overload and hepatocellular carcinoma (HA-7-0-080). Eur J Haematol 1998;60:28-34. DOI PubMed

205. Asare GA, Bronz M, Naidoo V, Kew MC. Interactions between aflatoxin B1 and dietary iron overload in hepatic mutagenesis. Toxicology 2007;234:157-66. DOI PubMed

206. Hassan MM, Hwang LY, Hatten CJ, et al. Risk factors for hepatocellular carcinoma: synergism of alcohol with viral hepatitis and diabetes mellitus. Hepatology 2002;36:1206-13. DOI PubMed

207. Stickel F, Schuppan D, Hahn EG, Seitz HK. Cocarcinogenic effects of alcohol in hepatocarcinogenesis. Gut 2002;51:132-9. DOI PubMed PMC

208. Schneider M, Norman R, Parry C, Bradshaw D, Plüddemann A; South African Comparative Risk Assessment Collaborating Group. Estimating the burden of disease attributable to alcohol use in South Africa in 2000. S Afr Med J 2007;97(8 Pt 2):664-72. PubMed

209. Mohamed AE, Kew MC, Groeneveld HT. Alcohol consumption as a risk factor for hepatocellular carcinoma in urban southern African blacks. Int J Cancer 1992;51:537-41. DOI PubMed

210. Donato F, Tagger A, Gelatti U, et al. Alcohol and hepatocellular carcinoma: the effect of lifetime intake and hepatitis virus infections in men and women. Am J Epidemiol 2002;155:323-31. DOI PubMed

211. Davis GL, Dempster J, Meler JD, et al. Hepatocellular carcinoma: management of an increasingly common problem. Proc (Bayl Univ Med Cent) 2008;21:266-80. DOI PubMed PMC

212. Morgan TR, Mandayam S, Jamal MM. Alcohol and hepatocellular carcinoma. Gastroenterology 2004;127:S87-96. DOI PubMed

213. Kew MC, Song E, Dusheiko GM. Hepatocellular carcinoma in white South Africans-aetiological considerations. S Afr Med J 1984;66:835-7. PubMed

214. . World Health Organization. Global status report on alcohol and health 2018. In: Poznyak V, Rekve D, editors; 2018.

215. Walbeek C. Measuring changes in the illicit cigarette market using government revenue data: the example of South Africa. Tob Control 2014;23:e69-74. DOI PubMed PMC

216. Kew MC, Dibisceglie AM, Paterson AC. Smoking as a risk factor in hepatocellular carcinoma a case-control study in southern African blacks. Cancer 1985;56:2315-7. DOI PubMed

217. Gao J, Xie L, Yang WS, et al. Risk factors of hepatocellular carcinoma--current status and perspectives. Asian Pac J Cancer Prev 2012;13:743-52. DOI PubMed

218. Hammond EC. Smoking in relation to the death rates of one million men and women. Natl Cancer Inst Monogr 1966;19:127-204. PubMed

219. Hirayama T. A large-scale cohort study on risk factors for primary liver cancer, with special reference to the role of cigarette smoking. Cancer Chemother Pharmacol 1989;23 Suppl:S114-7. DOI PubMed

220. Kuper H, Tzonou A, Kaklamani E, et al. Tobacco smoking, alcohol consumption and their interaction in the causation of hepatocellular carcinoma. Int J Cancer 2000;85:498-502. PubMed

221. Tu T, Budzinska MA, Shackel NA, Urban S. HBV DNA integration: molecular mechanisms and clinical implications. Viruses 2017;9:75. DOI PubMed PMC

222. Austin H, Delzell E, Grufferman S, et al. A case-control study of hepatocellular carcinoma and the hepatitis B virus, cigarette smoking, and alcohol consumption. Cancer Res 1986;46:962-6. PubMed

223. Tanaka K, Hirohata T, Takeshita S, et al. Hepatitis B virus, cigarette smoking and alcohol consumption in the development of hepatocellular carcinoma: a case-control study in Fukuoka, Japan. Int J Cancer 1992;51:509-14. DOI PubMed

224. Lee YC, Cohet C, Yang YC, Stayner L, Hashibe M, Straif K. Meta-analysis of epidemiologic studies on cigarette smoking and liver 
cancer. Int J Epidemiol 2009;38:1497-511. DOI PubMed

225. Abdel-Rahman O, Helbling D, Schöb O, et al. Cigarette smoking as a risk factor for the development of and mortality from hepatocellular carcinoma: an updated systematic review of 81 epidemiological studies. J Evid Based Med 2017;10:245-54. DOI PubMed

226. Ma F, Zhang Z, Jiang J, Hu J. Chromium (VI) potentiates the DNA adducts (O(6)-methylguanine) formation of Nnitrosodimethylamine in rat: implication on carcinogenic risk. Chemosphere 2015;139:256-9. DOI PubMed

227. Fadlallah S, Lachapelle M, Krzystyniak K, et al. O6-methylguanine-DNA adducts in rat lymphocytes after in vivo exposure to Nnitrosodimethylamine (NDMA). Int J Immunopharmacol 1994;16:583-91. DOI PubMed

228. Arinç E, Arslan S, Bozcaarmutlu A, Adali O. Effects of diabetes on rabbit kidney and lung CYP2E1 and CYP2B4 expression and drug metabolism and potentiation of carcinogenic activity of N-nitrosodimethylamine in kidney and lung. Food Chem Toxicol 2007;45:107-18. DOI PubMed

229. Guarino M, Dufour JF. Smoking favours hepatocellular carcinoma. Ann Transl Med 2019;7:S99. DOI PubMed PMC

230. Working Group on the Evaluation of Carcinogenic Risks to Humans. Tobacco smoke and involuntary smoking. IARC Monogr Eval Carcinog Risks Hum 2004;83:1-1438. PubMed PMC

231. Younossi ZM, Koenig AB, Abdelatif D, Fazel Y, Henry L, Wymer M. Global epidemiology of nonalcoholic fatty liver disease-Metaanalytic assessment of prevalence, incidence, and outcomes. Hepatology 2016;64:73-84. DOI PubMed

232. Adams LA, Lymp JF, St Sauver J, et al. The natural history of nonalcoholic fatty liver disease: a population-based cohort study. Gastroenterology 2005;129:113-21. DOI PubMed

233. Yatsuji S, Hashimoto E, Tobari M, Taniai M, Tokushige K, Shiratori K. Clinical features and outcomes of cirrhosis due to nonalcoholic steatohepatitis compared with cirrhosis caused by chronic hepatitis C. J Gastroenterol Hepatol 2009;24:248-54. DOI PubMed

234. Charrez B, Qiao L, Hebbard L. Hepatocellular carcinoma and non-alcoholic steatohepatitis: The state of play. World J Gastroenterol 2016;22:2494-502. DOI PubMed PMC

235. Jiang CM, Pu CW, Hou YH, Chen Z, Alanazy M, Hebbard L. Non alcoholic steatohepatitis a precursor for hepatocellular carcinoma development. World J Gastroenterol 2014;20:16464-73. DOI PubMed PMC

236. Nagaoki Y, Hyogo H, Aikata H, et al. Recent trend of clinical features in patients with hepatocellular carcinoma. Hepatol Res 2012;42:368-75. DOI PubMed

237. Fingas CD, Best J, Sowa JP, Canbay A. Epidemiology of nonalcoholic steatohepatitis and hepatocellular carcinoma. Clin Liver Dis (Hoboken) 2016;8:119-22. DOI PubMed PMC

238. Larsson SC, Wolk A. Overweight, obesity and risk of liver cancer: a meta-analysis of cohort studies. Br J Cancer 2007;97:1005-8. DOI PubMed PMC

239. Risk Factor Collaboration (NCD-RisC) - Africa Working Group. Trends in obesity and diabetes across Africa from 1980 to 2014: an analysis of pooled population-based studies. Int J Epidemiol 2017;46:1421-32. DOI PubMed PMC

240. Brandt S, Heller H, Schuster KD, Grote J. Tamoxifen induces suppression of cell viability and apoptosis in the human hepatoblastoma cell line HepG2 via down-regulation of telomerase activity. Liver Int 2004;24:46-54. DOI PubMed

241. Guo R, Huang Z, Shu Y, Jin S, Ge H. Tamoxifen inhibits proliferation and induces apoptosis in human hepatocellular carcinoma cell line HepG2 via down-regulation of survivin expression. Biomed Pharmacother 2009;63:375-9. DOI PubMed

242. Benedetti VM, Welsh JA, Yu MC, Bennett WP. p53 mutations in hepatocellular carcinoma related to oral contraceptive use. Carcinogenesis 1996;17:145-9. DOI PubMed

243. Lindberg MC. Hepatobiliary complications of oral contraceptives. J Gen Intern Med 1992;7:199-209. DOI PubMed

244. Hannaford PC, Kay CR, Vessey MP, Painter R, Mant J. Combined oral contraceptives and liver disease. Contraception 1997;55:14551. DOI PubMed

245. Fiel MI, Min A, Gerber MA, Faire B, Schwartz M, Thung SN. Hepatocellular carcinoma in long-term oral contraceptive use. Liver 1996;16:372-6. DOI PubMed

246. World Health Organization. HIV/AIDS 2019. Available from https://www.who.int/news-room/fact-sheets/detail/hiv-aids\#. [Last accessed on 7 May 2021].

247. Matthews PC, Geretti AM, Goulder PJ, Klenerman P. Epidemiology and impact of HIV coinfection with hepatitis B and hepatitis C viruses in Sub-Saharan Africa. J Clin Virol 2014;61:20-33. DOI PubMed

248. Bell TG, Makondo E, Martinson NA, Kramvis A. Hepatitis B virus infection in human immunodeficiency virus infected southern African adults: occult or overt--that is the question. PLoS One 2012;7:e45750. DOI PubMed PMC

249. Yousif M, Mudawi H, Hussein W, et al. Genotyping and virological characteristics of hepatitis B virus in HIV-infected individuals in Sudan. Int J Infect Dis 2014;29:125-32. DOI PubMed

250. Thio CL, Seaberg EC, Skolasky R, et al. HIV-1, hepatitis B virus, and risk of liver-related mortality in the Multicenter Cohort Study (MACS). Lancet 2002;360:1921-6. DOI PubMed

251. Chun HM, Roediger MP, Hullsiek KH, et al; Infectious Disease Clinical Research Program HIV Working Group. Hepatitis B virus coinfection negatively impacts HIV outcomes in HIV seroconverters. J Infect Dis 2012;205:185-93. DOI PubMed PMC

252. Thomas DL. Growing importance of liver disease in HIV-infected persons. Hepatology 2006;43:S221-9. DOI PubMed

253. Stein L, Urban MI, O'Connell D, et al. The spectrum of human immunodeficiency virus-associated cancers in a South African black population: results from a case-control study, 1995-2004. Int J Cancer 2008;122:2260-5. DOI PubMed

254. Mbulaiteye SM, Katabira ET, Wabinga H, et al. Spectrum of cancers among HIV-infected persons in Africa: the Uganda AIDSCancer Registry Match Study. Int J Cancer 2006;118:985-90. DOI PubMed 
255. Engels EA, Biggar RJ, Hall HI, et al. Cancer risk in people infected with human immunodeficiency virus in the United States. Int $J$ Cancer 2008;123:187-94. DOI PubMed

256. Adam MA, Johnson LF. Estimation of adult antiretroviral treatment coverage in South Africa. S Afr Med J 2009;99:661-7. PubMed

257. Klausner JD, Serenata C, O'Bra H, et al. Scale-up and continuation of antiretroviral therapy in South African treatment programs, 2005-2009. J Acquir Immune Defic Syndr 2011;56:292-5. DOI PubMed

258. Mutyaba I, Phipps W, Krantz EM, et al. A Population-Level Evaluation of the Effect of Antiretroviral Therapy on Cancer Incidence in Kyadondo County, Uganda, 1999-2008. J Acquir Immune Defic Syndr 2015;69:481-6. DOI PubMed PMC

259. Price JC, Thio CL. Liver disease in the HIV-infected individual. Clin Gastroenterol Hepatol 2010;8:1002-12. DOI PubMed PMC

260. Dionne-Odom J, Njei B, Tita ATN. Elimination of Vertical Transmission of Hepatitis B in Africa: A Review of Available Tools and New Opportunities. Clin Ther 2018;40:1255-67. DOI PubMed PMC 